\title{
The Executive Investigates Itself
}

\author{
Frank M. Tuerkheimer ${ }^{\dagger}$
}

Professor Tuerkheimer evaluates proposals to assure impartiality when prosecutors investigate possible criminality within their governments. At the federal level he argues that Congress should block partisan appointments to the Justice Department rather than create a permanent special prosecutor's office. He finds that the states are capable of adequately prosecuting corruption at lower levels of state government, but that they must presently depend on the federal government for prosecution of high level executive officials.

Because it is organized under an elected Chief Executive, the functions of the federal executive branch are inevitably colored by the partisan nature of the Presidency. Law enforcenient is an executive function, ${ }^{1}$ but while partisan considerations are understandably a con1ponent of most executive decisionnaking, criminal laws should be enforced without partisan bias. The partisan instincts of the executive collide most noticeably with the supposedly nonpartisan nature of law enforcement when the executive branch investigates itself and prosecutes the crimes of governnent officials. ${ }^{2}$

$\dagger$ B.A. 1960, Columbia College; LL.B. 1963, New York University; member, Wisconsin and New York Bars; and Professor of Law, University of Wisconsin School of Law. The author served as an associate special prosecutor with the Watergate Special Prosecution Force from December 1973 to June 1975. A grant from the Wisconsin Foundation supported the research for this Article. The author is indebted to Ms. Jann Ozzello, a third-year student at the University of Wisconsin School of Law, for her assistance. [Ed.] Professor Tuerkheimer is the new United States Attorney for the Western District of Wisconsin.

1. United States v. Nixon, 418 U.S. 683, 693 (1974). See also Newman v. United States, 382 F.2d 479 (D.C. Cir. 1967).

2. The scope of this problem should not be exaggerated, because the lower levels of executive departments are staffed by nonpartisans. For example, there were over 49,000 employees in the Justice Department in 1974. ANNUAL REPORT OF THE ATTORNEY GENERAL OF THE UNTTED STATES 41 (1974). It is likely that many of these employees were hired without regard to party affiliation. A former head of the Crimmal Frauds Section of the Justice Department is reported to have said:

The Justice Department is a set of files in a goldfish bowl. When you have one of these cases and it involves agents, an assistant U.S. attorney, some lawyers from the Organized Crime Section, the head of the Organized Crime Section, an Assistant Attorney General and the Deputy Attorney General, not to mention subpoena servers, marshals, secretaries, etc., do you think the Attorney General can just say "Shshsh" . . . and it will go away?

V. NAVASKY, KENNEDY JUSTICE 377 (1971) [hereinafter cited as V. NAVASKY]. 
This Article will consider cases where executive branches of both federal and state governments have investigated their own officials. Some emphasis will be given to cases involving alleged criminality in the law enforcement cham-of-command, where the danger of conflict is greatest.

In the federal government all executive power is derived from the Presidency, while in the states it is quite diffused ${ }^{3}$ and usually organized under three constitutional offices-Governor, attorney general, and district attorney. Because of these structural differences, federal and state law enforcement systems will be analyzed separately. Part I will discuss the structure of federal law enforcement and review specific cases involving partisan conflicts. It will then assess the ability of the present system to handle these difficult cases and evaluate various proposals for reform. Part II will review the record of state systems in prosecuting corruption at different levels of government and consider the involvement of the federal government in the prosecution of state officials.

\section{I}

\section{The Federal Government}

\section{A. Structure and Staffing}

Article II, section 1 of the United States Constitution directs that "[t]he executive Power shall be vested im a President of the United States of America",4 Section 3 requires that the President "take Care that the Laws be faithfully executed." 5 Although the Constitution does not create executive departments, it obviously contemplates internal delegation of executive power to such departments by providing that the President shall appoimt other officers with the advice and consent of the Senate, that Congress may vest the appointment of inferior officers "in

3. In 1974 , there were 2,637 attorneys in the United States authorized to bring criminal charges under state law. 1974 National DiRECTORY of Law ENFoRCEMENT ADMiNisTrators 2-63. In most instances there was one such official for each county; in some cases counties were grouped to form "districts"; and in Delaware and Rhode Island major criminal cases are handled by the state attorney general. In addition there is one United States attorney for each of 94 federal judicial districts. 28 U.S.C. $\$ \S$ 81-131 (1970). See 1976 National Directory of LaW ENForcement AdministraTORS 136-42. Most of these district attorneys and United States attorneys have assistants. See, e.g., WIs. Srat. ANN. $\$ 59.45$ (West Supp. 1976); 28 U.S.C. $\$ 542$ (1970). In some cases there may be several hundred. See, e.g., National District AtTorneys association, Report on Proceedings, Recommendations and Statistics of the NDAA Metropolitan Prosecutors' Conference, Chart I, at 41 (1970). There were 1,458 assistants in the 94 United States attorneys' offices in 1975, the largest number, 99, in the Southern District of New York. U.S. DEP'T OF JUSTICE, UNITED STATES AtToRneys' OfFices Statistical RePort, Fiscal YeAR 1975, Table 6 (1975).

4. U.S. CoNST. art. II, § 1, cl. 1.

5. Id. \&3. 
the President alone, in the Courts of Law, or in the Heads of Departments" and that the President may require written opinions of each department's principal officer. ${ }^{6}$

Pursuant to this constitutional delegation of power, the First Congress in the Judiciary Act of 1789 created the office of the Attorney General, providing that "there shall also be appointed a meet person, learned in the law to act as attorney general for the United States." the same time, Congress created the office of United States attorney in each judicial district, charging that office with the duty to prosecute violations of federal law occurring within the district. ${ }^{8}$

The prosecuting arm of federal law enforcement machinery has since expanded enormously. A Department of Justice was created in $1870 .^{9}$ Under the Attorney General is a Deputy Attorney General, a Presidential appointee subject to Senate confirmation. ${ }^{10}$ The bulk of the Department of Justice is divided into various divisions, each headed by an Assistant Attorney General, also a Presidential appointee subject to Senate confirmation. ${ }^{11}$ These divisions include the Criminal Division, ${ }^{12}$ in turn divided into various sections, each headed by a Deputy Assistant Attorney General. ${ }^{13}$ The Criminal Division is responsible for prosecutions of federal crimes not otherwise specifically assigned and for enforcement of certain specific statutes, such as the Civil Rights Acts, ${ }^{14}$ the Election Law, ${ }^{15}$ and the Labor-Management Reporting and Disclosure Act. ${ }^{16}$

The President is also empowered to appoint a United States attorney for each judicial district. The appointment, which is subject to

6. Id. $\$ 2$.

7. Act of September 24, 1789, ch. 20, $\$ 35,1$ Stat. 93. In Ponzi v. Fessenden, 258 U.S. 254, 262 (1922), the Supreme Court stated, "The Attorney General is the head of the Department of Justice. ... He is the hand of the President in taking care that the laws of the United States . . . in the prosecution of offences, be faithfully executed."

8. Act of Sept. 24, 1789, ch. $20, \S 35,1$ Stat. 92.

9. Act of June 22,1870 , ch. $150, \S 1,16$ Stat. 162 (current version at 28 U.S.C. $\S 503(1970)$ ). Until 1850, the Attorney General's staff consisted of three people: the Attorney General, a clerk, and a messenger. See W. Seymour, UnTted STATES ATTORNEY 22 (1975). [hereinafter cited as W. SEYMOUR]. See generally H. CUMmINGS \& C. MCFARLAND, Federal JUSTICE 83-160 (1937).

10. 28 U.S.C. $\$ 504$ (1970).

11. Id. § 506 .

12. 28 C.F.R. $\S \S 0.55-64$ (1976). The Assistant Attorney General in charge of the Criminal Division in turn may appoint deputies and assistants. See id. $\$ \S 0.59$, 0.64 .

13. U.S. Dep't of Justice, ANNuAl Report of the AtTorney General of the UNITED STATES 86 (1974).

14. 28 C.F.R. $\$ 0.50$ (a) (1976).

15. Id. $\$ 0.55(\mathrm{~m})(1)-(2)$.

16. 28 C.F.R. $\$ 0.55(l)(1976)$. 
Senate confirmation, is for a 4-year term although each United States attorney is subject to removal by the President. ${ }^{17}$ The Attorney General is authorized to appoint and remove assistant United States attorneys ${ }^{18}$ but in practice the local United States attorney usually exercises this power. ${ }^{19}$ The Attorney General is also authorized to appoint and remove special attorneys to assist a United States attorney. ${ }^{20}$ The United States attorney is principally required to prosecute all federal offenses and to represent the United States in civil litigation. ${ }^{21}$

Although supervision of United States attorneys is technically in the hands of the Executive Office for United States Attorneys-part of the office of the Deputy Attorney General ${ }^{22}$ - the Assistant Attorney General in charge of the Criminal Division exercises such supervision in criminal matters. ${ }^{23}$ The overlap of prosecutors' jurisdiction between the United States attorney and the Criminal Division ${ }^{24}$ creates a muddled delineation of power, resolved more by precedent and personality than by bureaucratic guidelines. ${ }^{25}$ Certain United States attorneys' offices have traditionally had exclusive jurisdiction over all federal offenses, except antitrust violations, occurring in their districts; others have ineshed their jurisdiction with the Justice Department. ${ }^{26}$ Shared jurisdiction is often necessary when the United States attorney in a small district lacks sufficient staffing to conduct a complex and difficult criminal prosecution.

17. 28 U.S.C. \& 541 (1970).

18. Id. $\$ 542$.

19. As of June 30,1975 , there were 1,458 assistant United States attorneys. See note 3 supra. There is no way the Attorney General could be the moving force in such a large number of appointments, even if he wanted to be.

20. 28 U.S.C. $\& 543(1970)$.

21. Id. $\$ 547$.

22. 28 C.F.R. $\$ 0.16$ (1976). Originally, United States attorneys were answerable only to the President and not to the Attorney General. The advent of the Civil War began the process of subordinating United States attorneys to the Attorney General, a process that continued for 50 years. See W. SEYMOUR, supra note 9, at 46.

23. See National Archives and Records Service, Office of the Federal RegISTER, UNITED STATES GOVERNMENT MANUAL 314 (1975-76 ed.).

24. Compare 28 U.S.C. $\$ 547$ (1970) with 28 C.F.R. $\$ 0.55$ (1976).

25. Emory Buckner, United States attorney for the Southern District of New York, discussed his relationship with the Attorney General in a letter to his daughter: "He is my superior, but the relationship is anonymous, and it has never been determined just what the hegemony is. It differs with different men." Letter to Ruth Buckner (Mar. 7, 1926), quoted in M. MAYER, EMORY BuckNer 176 (1968) [hereinafter cited as M. MAYER].

26. Sometimes, the Department will take over an investigation if it believes that the local United States attorney will not act or lacks the necessary skill. See United States v. Lester, 363 F.2d 68 (6th Cir. 1966), cert. denied, 385 U.S. 1002 (1967); V. NAvASKY, supra note 2, at 54; Jackson, The Federal Prosecutor, 31 J. CRIM. L.C. \& P.S. 3, 3-4 (1940). 
Although nonpolitical Attorneys General have been appointed in this century, ${ }^{27}$ most Presidents have appointed men who have worked closely with them on political matters. ${ }^{28}$ The Deputy Attorney General often had an equally partisan background. A blatant example of continuing partisanship is Deputy Attorney General Kliendienst's remark to a 1971 conference of United States attorneys: "[1]t is of utmost importance to keep this Administration in power and you men inust do everything you can to insure that result." ${ }^{29}$ President Ford's appointment of Edward S. Levi, a distinguished academic lawyer with no discernible partisan ties, as Attorney General and Harold Tyler, Jr., a former Kennedy appointee to the bench, ${ }^{30}$ as Deputy Attorney General marked a sharp deviation froin these precedents. President Coolidge appointed Dean Harlan F. Stone ${ }^{31}$ of the Columbia Law School to replace Harry Daugherty, ${ }^{32}$ but these are rare deviations from general practice.

The men chosen by President Carter to head the Justice Departnient have definite Democratic political connections, but these connections do not appear to have played a primary role in their selection. Although Attorney General Griffin Bell was a law partner of the President's close political confidant, Charles Kirbo, he has had a long independent career as a federal appellate judge and was not actively involved in the Presidential campaign. ${ }^{33}$ Deputy Attorney General Peter Flaherty, as mayor of Pittsburgh, was one of the first urban Deniocratic leaders to support Carter for President. ${ }^{34}$ But Carter's first

27. See note 30 infra and accompanying text.

28. Presidents Harding (N.Y. Times, Feb. 27, 1921, \& 7, at 4, col. 4), Truman (52 National CyClopaedia of AMERICAN BIography 349 (1970)), Eisenhower ([Current Vol. I 1953-59] id. 350 (1960)), Kennedy ([Current Vol. J 1960-63] id. 28 (1964)), and Nixon (N.Y. Times, Dec. 12, 1968, at 1, col. 8) appointed their campaign managers. Homer Cummings, Franklin Roosevelt's first Attorney General, had been chairman of the Democratic National Committee. W. SEYMOUR, supra note 9, at 79.

29. W. SEYMOUR, supra note 9, at 226. Seymour also reported that Kleindienst instructed the United States attorneys to "avoid controversies that might lose votes." Id. at 226-27. None of the assertions by Seymour has been challenged either by Kleindienst or by the hundreds of witnesses to the remarks. Telephone interview with Whitney North Seymour, Jr. (June 22, 1976).

30. Tyler had also been a Justice Department attorney during the Eisenhower administration.

31. L. Huston, The Department of Justice 42 (1967); see N.Y. Times, Apr. 3,1924 , at 1 , col. 8 ; id. at 20 , col. 1 .

32. See text accoinpanying notes $49-59$ infra.

33. See generally Navasky, The Greening of Griffin Bell, N.Y. Times, Feb. 27, 1977, $₹ 6$ (Magazine), at 41-50. Since Mr. Bell had not been involved in politics in recent years, he would have been eligible for appointment as Special Prosecutor under S. 495, 94th Cong., 1st Sess. (1976), a bill designed to create a nonpartisan watclidog operation within the Justice Department. See text accompanying notes 166-73 infra.

34. N.Y. Times, Feb. 22, 1977, at 1, col. 1; and at 18, col. 3. 
choice for that position was Frank Johnson, then a federal judge and obviously not involved in the campaign. ${ }^{35}$ Most other leading positions in the Department have not been filled by politicians. ${ }^{38}$ There is little reason to believe that President Carter wishes to make his Justice Department a political arm of the White House, but an informed judgment cannot be made without an opportunity to evaluate the Department's performance. ${ }^{37}$

The Assistant Attorney General in charge of the Crimimal Division has sometimes been selected on the basis of political activity. ${ }^{88}$ President Carter has selected Benjamin Civiletti, a former assistant United States attorney in the Kennedy Administration who has served repeatedly as campaign treasurer for Senator Sarbanes, a Maryland Democrat. ${ }^{30}$

But United States attorneys imvariably belong to a newly elected President's party. ${ }^{40}$ Whether a United States attorney functions independently and without partisan bias, or as a subservient political appointee, depends on his personality and the traditions of his local office. Some of the most dramatic prosecutions of highly placed executive officials have been brought by United States attorneys of the same party as the defendant or the President who appointed them both. Whether an assistant United States attorney is a "political" appointment in the

35. Id.

36. President Carter's choices for Solicitor General and Assistant Attorneys General in charge of the Civil Rights Division, the Civil Division, and Legislative Affairs have been a United States Court of Appeals Judge, an NAACP attorney, a Stanford law professor, and a director of the Mental Health Law Project, respectively. Id., Feb. 16, 1977, at A15, col. 1. Attorney General Bell appointed a former Republican Legislator from Georgia as Associate Attorney General. Department of Justice Release, March 10, 1977.

37. In his analysis of the Justice Departanent's first weeks under Griffin Bell, Victor Navasky observes that the presence in Bell's inner circle of consumer activists and alumni of protest novements may convert Bell "from establishment apologist to tribune for the public interest." Navasky, supra note 33, at 50. But see Safire, President Carter's First Cover-Up, N.Y. Times, Mar. 3, 1977, at 33, col. 4 ("All in all, the politicization of the [Carter] Justice Department has progressed to a point that would have made John Mitchell blush.").

38. Jack Miller, the first Kennedy appointee to that position, was a Republican. V. NAvaskY, supra note 2, at 52-53. Will Wilson, Mr. Nixon's first appointee, had been active in Nixon's 1968 campaign, but Nixon's second appointee, Henry Petersen, was a career employee of the Justice Department and a Democrat. N.Y. Times, Jan. 12, 1972, at 28, col. 8. Richard Thornburg, President Ford's selection, had run for Congress as a Republican and had been appointed by Nixon as United States attorney for the Western District of Pennsylvania.

39. See Safire, supra note 37. Safire also alludes to a connection between Kirbo and Civiletti based on dealings between their respective law firms.

40. When New York's Democratic Senator Daniel P. Moynihan recently "[broke] with tradition" by announcing that he favored the retention of incumbent (Republican) United States attorneys, local Democrats were reportedly "imcensed" over the loss of patronage involved. N.Y. Times, Jan. 19, 1977, at 1, col. 4. 
sense that he must be active in party affairs or have the support of someone who is, is also a function of the tradition of the particular United States attorney's office. Assistants in the larger offices are generally appointed without regard to such considerations, ${ }^{41}$ as are Justice Department lawyers below the level of Deputy Assistant Attorney General.

With this brief review of the structure of the federal prosecutorial system im mind, some of the major cases that have taxed the ability of this structure to police itself may be examined.

\section{B. Cases}

\section{Harding Administration Scandals ${ }^{2}$}

Investigations of alleged corruption in the Harding Administration resulted in a large number of charges, including the imdictment of two Harding cabimet menibers: Secretary of the Interior Albert Fall and Attorney General Harry Daugherty.

\section{a. Attorney General Daugherty}

Former Attorney General Daugherty was accused of fraud in connection with a release of assets held by the Alien Property Custodian. During World War I, the Trading-With-the-Enemy-Statute ${ }^{43}$ authorized the government to seize assets of corporations owned by German interests. The assets of the American Metals Corporation were seized under this authority. After the war, these assets were transferred to the Alien Property Custodian, a subordinate official in the Justice Department, who was authorized to handle claims for their return.

In September 1921, a German national claimed that the assets of the American Metals Corporation had been seized illegally. The Alien Property Custodian and an Assistant Attorney General, both Harding appointees, subsequently approved the release of American Metals' assets worth $\$ 7$ million on the ground that the initial seizure was a inistake.

This transaction was questioned in the New York World in early 1922 and President Harding asked Attorney General Daugherty to investigate the matter. Daugherty obtained a letter from the Assistant

41. Id., Nov. 17, 1976, at 14, col. 1 .

42. For a general background of the scandals of the Harding Administration, see F. Allen, ONLy Yesterday 123-58 (1931); 6 M. Sullivan, OUR Times: THe UNITED States 1900-1925, THe Twenties 252-357 (1935) [hereinafter cited as M. SullivaN]; M. MAYER, supra note 20 , at 174-236.

43. Act of Oct. 6, 1917, ch. 106, 40 Stat. 411 (current version at 50 U.S.C. app. $\S 1(1970))$. 
Attorney General who had approved the release, stating that the transaction was an honest one and that the proof submitted by the claimant was the best prepared of thousands submitted. ${ }^{44}$ The issue arose again in a Senate investigation of the Justice Department. ${ }^{45}$ Daugherty's successor, Harlan F. Stone, appointed a special attorney to examine the transaction. An investigation conducted by a grand jury in the Southern District of New York under the special attorney revealed that shortly after release of the $\$ 7$ million, the claimant had given a prominent Republican $\$ 391,000$ in Liberty Bonds. Fifty thousand dollars worth of the bonds had been sold for the account of the Alien Property Custodian. The special attorney failed to trace the remaining $\$ 341,000$.

After the special attorney had resigned the United States attorney for the Southern District of New York, Emory Buckner, a Coolidge appointee, assumed responsibility for the investigation. ${ }^{40} \mathrm{He}$ traced soine of the remaining bonds to a Washington, Ohio, bank and found that former Attorney General Daugherty's brother was its president. The investigation also revealed that the Justice Department had issued transportation requisitions for Daugherty and another person fronı Washington, D.C., to Washington, Ohio, the day before the bonds were cashed at the bank. Other events, equally circumstantial, linked Daugherty to the bonds.

The special attorney's failure to trace bonds pointing to Daugherty was especially questionable since Harding had appointed him United States attorney for the Northern District of New York while Daugherty was in office. Moreover, upon his resignation a year later, the attorney received several recurrent appointments by Daugherty as his special assistant. $^{47}$

In May 1926, Buckner charged Daugherty and others with conspiracy to defraud the United States on the basis of the speedy release of American Metals' assets and payments inade for the release. Daugherty was tried twice; after two hung juries the case against him was dismissed. $^{48}$

44. M. MAYER, supra note 25 , at 210.

45. Id.; see also M. SullIvaN, supra note 42 , at 612.

46. Consistent with the notion that the United States attorney has exclusive jurisdiction over crimes in the Southern District of New York, Buckner agreed only reluctantly to permit the special attorney to handle the investigation. See letter from Emory Buckner to Felix Frankfurter (Nov. 4, 1925), quoted in M. MAYER, supra note 25, at 210. Frankfurter, interestingly enough, had inquired about what was happening because of his friendship with the indicted Alien Property Custodian.

47. Id. at 214.

48. The first jury deadlocked at 7-5 for conviction, and the second at 11-1 for conviction. Id. at 220, 234. The former Alien Property Custodian was convicted at the retrial. Id. at 234 . 


\section{b. Secretary of the Interior Fall}

The prosecution of former Secretary of the Interior Fall arose out of an investigation into the leasing of oil reserves in Teapot Dome, Wyoming. Pursuant to an act of Congress, United States oil reserves in Teapot Dome and in Elk Hills, Califorma, were transferred to the Secretary of the Navy to hold as a reserve for future needs. When it was discovered that the tapping of neighboring private reserves might diminish or threaten the oil owned by the United States Government, Secretary of the Interior Fall persuaded the Secretary of the Navy to transfer the government's interests in Teapot Dome and Elk Hills to the Department of the Interior. Thereafter, Fall leased the exploration rights in these reserves to two private companies, one headed by Harry F. Sinclair and the other by Edward L. Doheny.

The first suggestion of impropriety surfaced in April 1922, when one of Wyoming's United States Senators received a letter from a constituent questioning what appeared to the tapping of Teapot Dome reserves despite the apparent public policy of preserving thein. The Senator requested Fall to explain. After considerable delay Fall nrade public the hitherto private lease of exploitation rights in Teapot Doine to Sinclair and also revealed that similar leases of the Elk Hills reserves to Doheny were being prepared. He justified the secrecy of the arrangement on national security grounds, contending that the leases affected the country's naval preparedness. ${ }^{49}$

Fall's explanation failed to satisfy Senator Robert LaFollette of Wisconsin. LaFollette obtained approval of a Senate resolution directing an inquiry regarding leases of naval oil reserves. ${ }^{50}$ After 18 months of private investigation, public hearings began in October 1923. Fall, Doheny, and Sinclair all denied any wrongdoing or any illegal inducements for the leases. The investigation revealed, however, that Fall had acquired $\$ 100,000$ in 1922 . It was ultinately discovered that Doheny had "lent" Fall the nroney immediately prior to execution of the leases.

Harry Daugherty was still Attorney General at this time. Although he was not involved in Teapot Dome, Congressional leaders lacked confidence in his ability to oversee the investigation of his former cabinet colleague. Therefore, on February 2-3, 1924, the Senate and House of Representatives passed a joint resolution calling on President Coolidge to appoint special counsel independent of the Justice Department to investigate the matter, the appointments to be subject to Senate

49. M. Sullivan, supra note 42 , at 276-77.

50. Id. at 277. 
confirmation. ${ }^{51}$ Coolidge appointed Owen Roberts, a Republican lawyer, and Atlee Pomerene, a former Democratic Senator from Ohio, as prosecutors, and their appointments were confirmed. Roberts and Pomerene obtaimed judicial voidance of the secret oil leases and the indictment and conviction of Albert Fall. ${ }^{52}$ The material generated by the Walsh investigation formed the basis of both the civil suit and the criminal prosecution. ${ }^{53}$

When Congress called on the President to appoint the special attorneys to investigate the leasing of naval reserves, President Harding, the incumbent at the time of the leases, was dead and there was no indication that President Coolidge was involved in the matter. Thus it was necessary to by-pass only the Justice Department, not the entire executive branch, to insure an independent imvestigation.

\section{Keogh-Kahaner Prosecution}

The bribery prosecution of Vincent Keogh and Elliott Kahaner is especially mstructive to this analysis. Kahaner was an assistant United States attorney and formerly acting United States attorney for the Eastern District of New York. Keogh, a Justice of the New York Supreme Court, was the brother of Congressman Eugene Keogh, who helped to ahin the New York Democratic delegation behind John Kennedy in 1960 and who was instrumental in obtaining his nomination. ${ }^{54}$ The discovery of Kahaner's and Vincent Keogh's crimmal involvement was entirely fortuitous. While an attorney for the Organized Crime Section of the Justice Department was interviewing one Sanford J. Moore-who had been sentenced for his part in a bankruptcy fraud-in a federal detention center, Moore noticed Kahaner escorting Attorney General Robert Kennedy on a tour of the center. Moore then told the attorney that Kahaner and Keogh has been paid to ask a federal judge for a lenient sentence for Moore. Moore's statement was corrobated by the person who had allegedly made the payments. ${ }^{.5}$

51. S.J. Res. 54, 68th Cong., 1st Sess. 43 Stat. 5 (1924). M. SullivaN, supra note 42 , at 345-46. Daugherty resigned as Attorney General several weeks later, on March 28, 1924. See L. Huston, supra note 31, at 253.

52. Fall is the only person of Cabinet rank ever convicted of a criminal violation committed while in the Cabinet. Maurice Stans, John Mitchell, and John Connally, charged with such violations in 1973 and 1974, were all aequitted. See text accompanying note 73 infra. The Daugherty prosecution ended with two mistrials. See note 48 supra and accompanying text. John Mitchell was convicted in the Watergate case for crimes occurring after his tenure as Attorney General. See Indictment at 2-3, United States v. Mitchell, Cr. No. 74-110 (D.D.C., filed Mar. 1, 1974).

53. See United States v. Fall, 10 F.2d 648 (D.C. Cir. 1925), cert. denied, 281 U.S. 757 (1930).

54. V. NAVASEY, supra note 2, at 364-65.

55. Id. at $367-68$. 
Because of the close connection between the Keogh and Kennedy families, the decision to investigate was an extremely sensitive one for the Attorney General. ${ }^{56}$ Nevertheless, Kennedy placed William Hundley, head of the Organized Crime Section under President Eisenlower, in charge of the investigation. ${ }^{57}$ Keogl, Kalianer, and Moore were indicted and convicted. ${ }^{58}$

\section{Nixon Administration Scandals}

\section{a. Harry Steward}

In a 1972 investigation of possible election law violations, an assistant United States attorney in San Diego issued a grand jury subpoena to Frank Thornton, an advertising agency official. Thornton's agency was owned by C. Arnholt Smith, a close friend of Richard Nixon. ${ }^{59}$ The assistant souglit to discover wliether the agency had been the conduit for an illegal contribution by International Telephone and Telegraph to the 1968 Nixon campaign.

When Harry Steward, the United States attorney for the Southern District of California, found out about the Thornton subpoena, he directed that it be withdrawn and instead interviewed Thornton personally. According to Steward's later testimony at the confirmation hearings of Attorney General designate Richard Kleindienst, ${ }^{80}$ Thornton very likely had been responsible for Steward's appointment as United States' attorney. ${ }^{11}$ Before the appoimtment Thornton had also worked witl him as a fund raiser ${ }^{62}$ and local campaign manager ${ }^{63}$ for Republican candidates. As to the contribution, Steward testified that Thornton had adequately explained the transaction during their interview, althougl lie could not remember how..$^{04}$ The investigation was closed. ${ }^{65}$ Had Thornton knowingly been a party to an illegal contribution, he

56. Id. at $362-74$.

57. Id. at 369.

58. United States v. Kahaner, 317 F.2d 459 (2d Cir.), cert. denied, 375 U.S. 835 (1963).

59. N.Y. Times, Apr. 12, 1972, at 18, col. 6.

60. Hearings Before the Comm. on the Judiciary, United States Senate, on Nomination of Richard G. Kleindienst, of Arizona, to be Attorney General, 92 Cong., 2d Sess., pt. 3, at 1433 (1972).

61. N.Y. Times, Apr. 12, 1972, at 18, col. 6.

62. Id.

63. Thornton had managed the San Diego campaigns of Eisenhower, Nixon, Goldwater, and others. Id., Apr. 19, 1972, at 1, col. 2.

64. Hearings, supra note 60 , pt. 3 , at 1437-39.

65. Id. Smith, however, was subsequently indicted on unrelated charges. United States v. Smith, Cr. No. 74-2475 (S.D. Cal. Dec. 31, 1974); United States v. Smith, Cr. No. 75-1324 (S.D. Cal. July 2, 1974). 
could have been prosecuted for his role. ${ }^{6 B}$

In March 1972, Life magazine alleged that Steward had halted various criminal investigations of prominent Southern California Republicans, and it expressly referred to the Thornton subpoena incident. ${ }^{67}$ The article triggered an investigation by Henry Petersen, Assistant Attorney General in charge of the Criminal Division. Petersen recoininended to the Deputy Attorney General, Richard Kleindienst, that Steward not be fired, since there was no evidence that he benefited financially, but that he be admonished for having failed to remove hinself fron 1 an investigation involving a close friend. ${ }^{88}$ Kleindienst agreed and Steward remained as United States attorney until the fall of $1975 .^{\circ 9}$

\section{b. Mitchell-Stans}

On May 10, 1973, the United States attorney for the Southern District of New York, Whitney North Seyinour, Jr., announced an indictment against Maurice H. Stans, fornter Secretary of Commerce in the Nixon Administration and former head of the Finance Committee to Re-Elect the President, and John N. Mitchell, Mr. Nixon's former Attorney General and campaign inanager. Seymour himself had been appointed by President Nixon while Mitchell was Attorney General. ${ }^{70}$ Both Mitchell and Stans were charged with perjury, but the heart of the indictment was an allegation of conspiracy to defraud the United States. According to this charge, Mitchell and Stans had allegedly undertaken a number of efforts on behalf of Robert Vesco, a generous contributor to the Republican party, in connection with an SEC investigation of his activities, with knowledge that Vesco had secretly contributed $\$ 200$,000 to the Nixon campaign. ${ }^{71}$

66. See United States v. Chestnut, 533 F.2d 40 (2d Cir.), cert. denied, 97 S. Ct. 88 (1976).

67. Walsh \& Flaherty, Tampering with Justice in San Diego, in LIFE, Mar. 24, 1972, at 8.

68. N.Y. Times, Apr. 12, 1972, at 18, col. 6. Financial gain is not an element of the basic bribery section, 18 U.S.C. 201 (1970), which speaks of "a thing of value", nor is it essential for any obstruction of justice prosecution: political advantage, as much as money, can be the principal motivating factor. Cf. United States v. Lester, 363 F.2d 68 (6th Cir. 1966) (conspiracy to violate civil rights of candidate for sheriff).

69. The allegations against Steward were one of the focal points of the confirmation hearing held when Kleindienst was nominated to be Attorney General. N.Y. Times, Apr. 8, 1972, at 13, col. 4.

70. Iromically, Seymour's appointment was controversial because it removed his predecessor, Robert $M$. Morgenthau, a Democrat who had functioned in a nonpartisan capacity. Id., Dec. 18, 1969, at 1, col. 4.

71. Indictment, United States v. Mitchell, Cr. No, $73-439$ (S.D.N.Y., filed May 10, 1973). 
Assistant United States attorneys conducted the investigation, primarily through staff investigators and the grand jury. No phase of the investigation was controlled by the Justice Department, which cooperated through Henry Petersen with the attorneys in the Southern District. The Department was informed of the proposed charges. which it approved the day before they were returned. ${ }^{72}$ Mitchell and Stans were subsequently acquitted of all charges. ${ }^{73}$

\section{c. Watergate}

The investigation into the Watergate burglary was begun by the United States Attorney's Office for the District of Columbia in conjunction with the FBI. From the beginning of the investigation until the advent of the Special Prosecutor, the investigators were under the watchful eyes of the investigated. When the FBI interviewed witnesses during the original investigation of the break-in, John Dean, counsel to the President, was present to monitor the investigation. ${ }^{74} \mathrm{~A}$ year later, when Dean and others were providing critical information to the assistant United States attorneys handling the investigation, the President was kept fully infornied of developments by Henry Petersen, head of the Criminal Division; ${ }^{75}$ President Nixon specifically directed Petersen to inforn him of any evidence Dean gave that involved the President. ${ }^{78}$

By April 1973, it was obvious that Mitchell and Robert Mardian, a former Assistant Attorney General, were among the targets of the

72. Telephone interview with James Rayhill (June 15, 1976). See generally W. SEYMOUR, supra note 9 , at 70-73.

73. The case of former Vice President Spiro Agnew involved similarly nonpolitical investigative efforts. Under the supervision of a Republican United States attorney, three assistant United States attorneys in the District of Maryland investigated possible kickbacks to publicly elected officials in Maryland. As they accumulated evidence pointing to Agnew, first the United States attorney, then Henry Petersen, and finally Attomey General Richardson became involved in the prosecution. See R. COHEN \& J. Witcover, A Heartbeat Away 15, 146-52 (1974).

74. John Ehrlichman had told Patrick Gray, Acting Chief of the FBI, that Dean would conduct a White House inquiry, including sitting in on FBI interviews of White House personnel. Meanwhile, Gray kept Dean informed on the theories explored by the FBI. In addition, Dean received copies of FBI files, interview reports, and memoranda summarizing the status of the investigation, all of which were shown to Mitchell, Haldeman, and Ehrlichman. See Brief for the United States at 20-21, United States v. Haldeman, No. 75-1381 (D.C. Cir., filed Oct. 15, 1975).

75. See, e.g., Submission of Recorded Presmential Conversations to the Committee of the Judictary of the House of Representattves by President RrCHARD NIXON app. 37, at 966-79 (Apr. 30, 1974) (telephone conversation between the President and Petersen, Apr. 16, 1973 (8:58-9:14 p.m.)); id. app. 41, at 1095 (meeting between the President and Petersen, Oval Office, Apr. 17, 1973 (2:46-2:49 p.m.), in which Petersen tells that Fred LaRue, a former Mitchell subordinate, started to cry when asked to testify about Mitchell).

76. Id. app. 47, at 1258 (meeting between the President and Petersen, Oval Office, Apr. 27, 1973 (5:37-5:43 p.m.)). 
inquiry. Because Richard Kleindienst, then Attorney General, had close relationships with these potential defendants, he felt he could not be involved in the case. Kleindienst first recused himself ${ }^{77}$ and later resigned. ${ }^{78}$ His resignation began the process that removed the President from a position of power in the investigation concerning his own conduct. Until then, President Nixon had been able not only to remain abreast of the investigation, but to participate unobserved in efforts to frustrate it. ${ }^{79}$ Once, however, the Attorney General designate, Elliot Richardson, publicly committed himself to the appointment of an independent special prosecutor to handle the Watergate investigation, ${ }^{80}$ the snug liason between the investigator and the investigated came to an end.

The Watergate Special Prosecution Force was created by order of Attorney General Richardson ${ }^{81}$ in an attempt to resolve a conflict between the traditional notion that investigation and prosecution are executive functions and the common sense judgment that an impartial investigation of the President and his closest aides could not be conducted by the President's subordinates. The Special Prosecutor was formally made subordmate to the Attorney General, preserving the "executive" nature of his functions. He was given the greatest degree of independence possible, however, and was permitted to determine himself whether and to what extent he would inform or consult with the Attorney General about the conduct of his duties and responsibilities. This independence was fortified by the Attorney General's promise "not [to] countermand or interfere with the Special Prosecutor's decisions or actions" and the understanding that the Special Prosecutor "[would] not be removed from his duties except for extraordinary improprieties on his part." The Special Prosecutor was also specifically given "full authority . . . for determining whether or not to contest the assertion of 'Executive Privilege' or any other testimomial privilege."

77. Memo from Richard Kleindienst to Henry Petersen (Apr. 15, 1973), reprinted in Hearings Before the Senate Select Comm. on Presidential Campaign Activities, 93d Cong., 1st Sess. 3860 (1973).

78. Id. at 3588.

79. See, e.g., SUbmission of Recorded Presidential Conversations, supra note 75, app. 6, at 185 (meeting between the President, Dean, and Haldeman, Oval Office, Mar. 21, 1973 (10:12 - 11:55 a.m.)).

80. E. Richardson, The Creative Balance 36 (1976) [hereinafter cited as E. RICHARDSON]. Richardson repeated his commitment to the Senate Judiciary Committee. Hearings Before the Senate Comm. on the Judiciary on the Nomination of Elliot $L$. Richardson of Massachusetts to be Attorney General, 93d Cong., 1st Sess. 4-6 (1973).

81. Exec. Order No. 517-73, 38 Fed. Reg. 14,688 (1973), reprinted in UNITED States Office of Watergate Special Prosecution Force, Report 245-47 (1975) [hereinafter cited as WATERGATE REPORT]; Hearings on the Nomination of Elliott $L$. Richardson, supra note 80, at 15-19.

82. Exec. Order No. 517-73, 38 Fed. Reg. 14,688 (1973), reprinted in Watergate REPORT, supra note 81 , at 245-47. 
ecutor Archibald Cox and the staff he selected continued and expanded the investigative work begun by the United States attorney's office. ${ }^{83}$

The accommodation reflected by Richardson's order broke down over the Special Prosecutor's use of judicial process to obtain tape recordings of presidential conversations. ${ }^{84}$ Cox refused to agree to Nixon's proposed compromise of the dispute over Cox's grand jury subpoena for Presidential tape recordings. The President ordered the Attorney General to dismiss Cox; instead, Richardson resigned. The Deputy Attorney General, William Ruckelshaus, who also refused to fire Cox, was disinissed. Solicitor General Robert Bork then became Acting Attorney General; lie acceded to the Presidents wishes by firing Cox and abolishing the Watergate Special Prosecution Force. ${ }^{85}$ The public response to this "Saturday Night Massacre" was extraordinary. According to Richardson, "tliree million messages descended on the Congress, the greatest outpouring of its kind that had ever taken place."

As a result, not only was the Special Prosecution Force reestablished, ${ }^{87}$ but it was given a greater guarantee of independence. The Special Prosecutor was given the same broad powers he had previously enjoyed, ${ }^{88}$ but in addition it was stipulated that he could be reinoved only upon a consensus of eight Congressional leaders. ${ }^{89}$ The appointment of Leon Jaworski followed and the Watergate Special Prosecution Force continued its work.

The President did not repeat his attempt to destroy the independence of the investigation into his own conduct. The President and the Special Prosecutor did collide over the amenability of Presidential tape recordings to a trial subpoena, but the dispute was resolved in the courts. ${ }^{90}$ Although the President urged in the litigation that his dispute with the Special Prosecutor was a "jurisdictional" dispute within the executive branch and therefore not justiciable, ${ }^{91}$ lie did so as a party urging acceptance of a legal argument, not as a Chief Executive ordering a subordinate to comply with his decision.

83. See Watergate RePort, supra note 81 , at 5-8, 11-20, 21-25.

84. See generally E. RICHARDSON, supra note 80 , at $38-47$.

85. Exec. Order No. 546-73, 28 C.F.R. $\$ 0.37$ app. (1973) (abolishing the Office of Watergate Special Prosecution Force), reprinted in WATERGATE REPORT, supra note 81, at 248-49. The Cox dismissal was held illegal because it did not comport with the existing order stating the couditions under which the Special Prosecutor could be removed. Nader v. Bork, 366 F. Supp. 104 (D.D.C. 1973).

86. E. RICHARDSON, supra note 80 , at 46.

87. Exec. Order No. 551-73, 28 C.F.R. $\$ \$ 0.37-.38$ (1976).

88. Exec. Order No. 551-73, 38 Fed. Reg. 30,738 (1973), as amended by Exec. Order No. 554-73, 38 Fed. Reg. 32,805 (1973), 28 C.F.R. $\$ 0.38$ app. (1976).

89. Id. The same requirement applied to any attempt to limit his jurisdiction.

90. United States v. Nixou, 418 U.S. 683 (1974).

91. See id. at 692-93. 


\section{Analysis}

\section{Is the System Adequate?}

Arguably, no change in the system is necessary because the present bureaucratic structure has generally worked well. Where the closest advisors to the President have been involved in possible criminal conduct, they have been subjected to investigatory and prosecutorial processes like anyone else. Indeed, in the one instance where the President himself had acted illegally, the present system was sufficiently flexible to prevent ultimate Presidential control of the investigation. Mr. Nixon was found by a grand jury to be a co-conspirator and was so named in a bill of particulars filed by his nominal subordinate. ${ }^{02}$ It might be contended that any defects in this system cannot justify the in terrorem effect on the federal bureaucracy of an alternative investigative and prosecutorial body outside the present Justice Department.

This position is not wholly tenable. First, it should be noted that in both instances where crimmal investigations reached the upper echelons of the cxecutive branch, Congress played a pivotal role. President Harding was unable to prevent the crippling Senate investigation that exposed the Teapot Dome scandal. ${ }^{93}$ The subsequent joint resolution requiring the appointment of a special prosecutor was merely the inevitable last blow of a thorough Congressional attack.

Similarly, the work of the Watergate Special Prosecution Force relied greatly on investigative work by Congress. As discussed above, the independence of the Special Prosecutor prevailed over Presidential power only because of the enormous public outcry that followed the Cox dismissal. Although it is difficult to identify causes of such massive, spontaneous public reactions, the televised hearings of the Senate Select Committee in the late spring and early suminer of 1973 were a principal catalyst. Public opmion was at least partially responsible for the President's decision to reinstate the Watergate Special Prosecution Force and to comply with the grand jury subpoena, which set in motion the events leading ultimately to his resignation. ${ }^{04}$

92. Brief for the United States at 12 , reprinted in A. WESTIN \& L. FRIEDMAN, United States v. Nixon, The President Before the Supreme Court 221-22 (1974).

93. See S. Res. 282, 67th Cong., 2d Sess., 62 CoNG. Rec. 6097 (1922) (58-0 vote in favor of an investigation of the oil leases).

94. The decision to reinstate the Watergate Special Prosecution Force and to comply with the grand jury subpoena led not only to the subsequent controversy over the "181/2 minute gap," which further eroded the President's political position, but to the disclosure of the March 21, 1973, recording revealing Mr. Nixon's involvement in the conspiracy to obstruct justice. The grand jury allegation of his involvement was, in turn, one reason why he was compelled to comply with the subsequent trial subpoena. 418 U.S. at 700-01. Compliance led directly to his resignation. See N.Y. Times, Aug. 9, 1974, at 1, col. 8. See generally B. Woodward \& C. Bernstein, The Final DaYS 405-509 (1977). 
Thus, whatever security may be derived from the thought that historically allegations of corruption have been vigorously pursued must be tempered by the acknowledgment that such pursuit was a function of the President's inability to prevent damaging Congressional investigations. ${ }^{95}$ It hardly seems consistent with the ideal of evenhandedness in the administration of justice that a President with sufficient political power to prevent congressional investigations might immunize himself from the law enforcement process. ${ }^{96}$

A second major difficulty with the argument that the system should not be changed is that the "system" is really two systems: one that permits politics and law enforcement to blend, and another that separates them. Within the past half-century the United States Attorney General has traditionally been the President's closest political advisor. Except for the prosecution of former Vice President Agnew, ${ }^{97}$ none of the corruption prosecutions of high ranking executive officials has emanated from the Justice Department. Former cabinet members have been charged with felony violations six times in our history; three of these prosecutions were brought by a special prosecutor, and the other three originated in the Southern District of New York, ${ }^{98}$ where prosecutors have followed a tradition of strict nonpartisanship and independence from the Justice Department. These prosecutions do not support the argument that the Justice Department itself should be left unchanged, since the system that produced them is atypical of the Department as a whole.

Finally, there is no assurance that the cases brought are the only ones that should have been brought. Especially below Cabinet level, where the officials concerned are not of sufficient rank to generate and sustain public interest, the disquieting question remains whether everything was done that should have been done.

The investigation of Harry Steward ${ }^{99}$ reveals a major problem in the assignment of responsibility for such cases. The Deputy Attorney General is entrusted by law with the supervision of United States attorneys. ${ }^{100}$ Thus the final decision on whether to take action against

95. By comparison, when Wright Patman, Chairman of the House Banking and Currency Committee, announced his intention to investigate the financing of the Watergate break-in, maneuvering by the White House and the Justice Department led to a 20-15 vote against Committee subpoena power, which effectively killed the investigation. 3 Hearings Before the Senate Select Comm. on Presidential Campaign Activities, 93d Cong., 1st Sess. 959-62, 1181-99 (1973) (testimony of John Dean).

96. See, e.g., A. STEINBERG, SAM Johnson's BOY 668-72 (1968) (Bobby Baker investigation).

97. See note 73 supra.

98. See text accompanying notes $44-48,70$ supra.

99. See text accompanying notes 56-69 supra.

100. 28 C.F.R. \$ 0.16 (1976). 
Steward for his concededly "improper conduct"101 in an investigation of President Nixon's campaign financing was made by a Nixon appointee chosen obviously for his political background. ${ }^{102}$ A case like Steward's impairs public confidence in the integrity of the decisionmaking process. ${ }^{103}$ Richard Kleindienst, who considered the political support of the Nixon administration a major mission of the Justice Department, ${ }^{104}$ was not the right person to make decisions about Harry Steward. Any Deputy selected because of past pohtical efforts is likely to share Kleindienst's views, to influence his associates, and to affect their official actions. As long as the highest positions in the Justice Department are filled on a partisan basis, there can be no confidence that all appropriate investigations will be pursued. Changes must be introduced if the law enforcers are to be subject to the laws in the same manner as other citizens and if we are to have public confidence in the integrity of federal law enforcement.

\section{Alternatives}

Although many suggestions for improving the system have been made ${ }^{105}$ the one most commonly urged is the appointment of a special prosecutor. ${ }^{108}$ But a permanent special prosecutor, set apart from the Justice Department, could not function effectively in many cases without its cooperation. He or his staff, mfluenced by a desire to justify their existence, might prosecute more cases than would be wise. Simple and basic changes, designed to depoliticize the Justice Department, would add far more to the system's ability to police itself.

\section{a. A Judicially Appointed Special Prosecutor}

The firing of Archibald Cox crystallized Congressional support for the judicial appointment of a special prosecutor who would be structur-

101. Henry Petersen agreed that Steward had engaged in "highly improper conduct." N.Y. Times, Apr. 12, 1972, at 18, col. 6.

102. Prior to becoming Deputy Attorney General in 1969, Richard Kleindeinst had not held a law enforcement position, but had been active in the Republican Party from 1953 to 1968. He ran for Governor of Arizona in 1964 and served as National Director of Field operations in the campaigns of Goldwater (1964) and Nixon (1968). MARQUTS' WHO'S WHO IN AMERICA 1721 (1974-75 ed.).

103. "[J]ustice inust satisfy the appearance of justice." Offutt v. United States, 348 U.S. 11, 14 (1954).

104. See text accoinpanying note 29 supra.

105. See, e.g., TIME, Dec. 3, 1973, at 73.

106. One minor reform instituted by Attorney General Riehardson and endorsed by former Attorney General Clark was the requirement that Justice Department personnel keep written memoranda of all contacts with persons not directly involved in a case, other than news media representatives. E. RiCHARDSON, supra note 80 , at 27 . 28; see R. Clark, Crisis at Justice 19 (Aug. 4, 1973) (unpublished address to Ralph Nader's Conference on the Legal Profession on file at the California Law Review). 
ally immune from Presidential removal. The constitutional authority for such an appointment would be article II, section 2, which provides that "Congress may by Law vest the Appointment of such inferior Officers, as they think proper, in the President alone, in the Courts of Law, or in the Heads of Departments." Fifty-four senators supported a bill creating such a position. ${ }^{107}$ The appointinent of Leon Jaworski apparently deflected the momentum behind the proposal. ${ }^{108}$ Nevertheless, the concept retains considerable support, and it must be analyzed in both constitutional and practical terms.

The hearings held by the Senate Judiciary Committee in late 1973 fully set forth the arguments for and against the constitutionality of a law authorizing a judicially appointed special prosecutor. ${ }^{109}$ The proponents relied on two cases construing article II, section 2: Ex Parte Siebold ${ }^{110}$ and Hobson v. Hansen. ${ }^{111}$ Opponents relied on an earlier Supreme Court decision, In re Hennen, ${ }^{112}$ the dissent in Hobson, and more recent cases emphasizing the executive nature of the law enforcement duty. ${ }^{113}$

In Siebold the Supreme Court sustained the constitutionality of a law authorizing a federal court to appoint election supervisors for a Congressional election. The Court observed that although it was usual and proper to vest the appointment of election officers in that branch of government to which the duties of the offices pertain, "there is no absolute requirement to this effect in the Constitution; and if there were, it would be difficult in inany cases to determine to which department an office properly belonged."114 The Court's conclusion that powers con-

107. See S. 2611, 93d Cong., 1st Sess., 119 Cong. REc. 39109 (1973). See also H.R. 11401, 93d Cong., 1st Sess., 119 CoNG. REC. 37902 (1973); H.R.J. Res. 784, 93d Cong., 1st Sess., 119 CoNg. REC. 34872 (1973).

108. In the period immediately following Leon Jaworski's appointment, the Watergate Special Prosecution Force vigorously searched for the origins of an $18 \frac{1}{2}$ minute gap in a Presidential tape recording turned over pursuant to a subpoena in a hearing before Judge Sirica, sought additional information from the White House, and secured charges against two former White House officials, Dwight Chapin and Egil Krogh. See NEw York TIMEs, The END of a Presmency 233-37 (1974). The special prosecutor bills never reached a vote. See F. MANRIEWICZ, U.S. v. Richard M. NIxON 61-62 (1975).

109. See Special Prosecutor: Hearings Before the Senate Judiciary Comm., 93d Cong., 1st Sess., pt. 1 (1973). Proponents of constitutionality included Professor Cox (id. at 19-34); Professor Freund (id. at 341-48); Professor Kurland (id. at 319-41); and Dean Paulsen (id. at 376-82). Opponents included Dean Cramton (id. at 34865 ); and the Justice Department Staff (id. at 37-40).

110. 100 U.S. 371 (1879).

111. 265 F. Supp. 902 (D.D.C. 1967).

112. 38 U.S. (13 Pet.) 230 (1839).

113. E.g., United States v. Newman, 382 F.2d 479 (D.C. Cir. 1967); United States v. Cox, 342 F.2d 167 (5th Cir.), cert. denied, 381 U.S. 935 (1965).

114. 100 U.S. at 397. Some support for a more restrictive construction is found in a passage from In re Hennen, 38 U.S. (13 Pet.) 230 (1839), where the Court upheld 
ferred by article $\Pi$, section 2 , were not conditioned by the function of the appointee ${ }^{115}$ was followed in Hobson, where a three-judge court upheld a law authorizing the district court to appoint inembers of the District of Columbia Board of Education.

Judge Wright dissented in Hobson. He postulated that a federal court's "first duty is . . . to guard zealously against inpairment of its own integrity as an institution," 116 a duty breached when the courts uphold a law imposing obligations totally unrelated to the judicial function. He cited a dictum in Siebold stating that judicial appointment of inferior officers, when required, is a constitutional duty "and in the present case there is no such incongruity in the duty required as to excuse the courts from its performance, or to render their acts void." 117 Judge Wright inferred that Congress could only require a federal court to appoint personnel "meaningfully affiliated with the judiciary,"118 and found that the Board of Education was not so affiliated. A comparable interpretation of article $\Pi$, section 2 , apparently underlies the position that a law authorizing judicial appointment of a special prosecutor would be unconstitutional. ${ }^{110}$ However one resolves this constitutional issue $^{120}$-and the weight of academic authority favors constitutionality ${ }^{121}$ - there remain several practical considerations not discussed in the

a law authorizing judges to appoint clerks. The Court said that "the appointing power here designated . . . was, no doubt, intended to be exercised by the department of the government to which the officer to be appointed most appropriately belonged." Id. at 257. In Siebold the Court stated that the Hennen dictum "was not intended to define the constitutional power of Congress in this regard, but rather to express the law or rule by which it should be governed." 100 U.S. at 398.

115. Presumably, under this approach Congress could constitutionally vest in the courts the power to appoint, for example, undersecretaries to cabinet members.

116. 265 F. Supp. at 919.

117. Id. at 921 (quoting 100 U.S. at 398).

118. $1 d$. at 925 .

119. Special Prosecutor: Hearings Before the Senate Judiciary Comm., 93d Cong., 1st Sess., pt. 1 at 39, 350 (1973).

120. The question was raised in United States v. Cowan, 524 F.2d 504 (5th Cir. 1975), cert. denied, 425 U.S. 971 (1976). The Government agreed to move to dismiss an indictment pending in the Northern District of Texas in exchange for a guilty plea in another case. The district court denicd the motion to dismiss the Texas charges. When the Government refused to proceed to trial, the court appointed special prosecutors to proceed in place of the United States attorney. On appeal, the special prosecutors argued that Congressional authorization for their appointment, pursuant to article II, $\S 2$, was implicit in FED. R. CRIM. P. 48(a), which requires the court's consent to the pretrial dismissal of an indictment. The Government urged that Rule 48(a) did not constitute such authorization, and that if it did, it would be unconstitutional. Since the Fifth Circuit held that the district court abused its limited discretion under Rule 48 (a) in refusing to dismiss the indictment, 524 F.2d at 513 , it did not reach the constitutional issue relevant here. (The author briefed and argued this case for the United States. [Ed.])

121. See note 109 supra. See also Letter of Philip B. Kurland to Senator Abe Ribicoff and Senator Charles H. Percy, Mar. 11, 1975, reprinted in FINAL REPORT, 
Senate hearings that argue against the creation of a permanent special prosecutor.

The nature of a special prosecutor's jurisdiction affects his staff's performance. Most prosecuting offices have jurisdiction over crimes committed within geographical limits, usually determined by county lines. ${ }^{122}$ The Watergate Special Prosecutor was given a very different jurisdictional base. He was authorized to imvestigate and prosecute possible violations of law in connection with the 1972 Presidential election-possible violations committed by Presidential appointees as well as other matters relating to the President. ${ }^{123}$ The Attorney General frequently expanded the scope of this authorization, ${ }^{124}$ but its general base, events, and people remained the same.

Where jurisdiction is grounded in geography, the past provides a guide so that an office can be adequately staffed to handle its work, which reaches such volume that the usual administrative problem is invariably one of decliming to prosecute probable criminality. Where territory forms the basis of jurisdiction, it is almost certain that there will be more crimes to prosecute than can be handled. ${ }^{125}$ Thus, there is no danger that the governmental bureaucracy will seek artificially to justify its existence. ${ }^{126}$

If jurisdiction rests on the drastically more limited basis of "an event" and "designated people," any assurance that there will be enough criminality to justify the existence of the prosecuting office is absent. Of course, the public interest is satisfied when a thorough investigation does not produce sufficient evidence of misconduct to warrant a charge, and a lawyer who concludes that no illegality has occurred will have done his job as well as a lawyer who obtains an indictment. But one inust be sensitive to the risk that lawyers working on an investigation will be made overzealous by a desire to "go public."

When there is insufficient evidence of any other crime, the perjury charge is an ideal vehicle for "going public." When complicated cases

Annual Chief Justice Earl Warren Conference on Advocacy in the Untred States of AMerica: The Powers of the Presidency 100-01 (Jun. 20-21, 1975).

122. See, e.g., 28 U.S.C. \$§ 81-131 (1970); N.Y. CouNTY LAW $\$ 700$ (McKinney 1972). See also Singh v. Superior Court, 44 Cal. App. 64, 65-66, 185 P. 985, 98586 (3d Dist. 1919).

123. 38 Fed. Reg. 14,688 (1973). See WATERgate Report, supra note 81, at $245-46$.

124. Compare the initial grant of jurisdiction, note 123 supra, with the docket of the Special Prosecution Force as of September 1, 1975, WATERGaTE REPORT, supra note 81, at 155-65.

125. See Jackson, supra note 26 , at 4-5.

126. Cf. Great Atl. \& Pac. Tea Co. v. Supermarket Equip. Corp., 340 U.S. 147, 156 (1950) (Douglas, J., concurring) (efforts of Patent Office to broaden definition of patentability and thus expand its own jurisdiction). 
are investigated, often years after the underlying events, grand jury testimony about those events almost inevitably varies. Whether variations represent real conflict and whether testimony has been motivated by a desire to conceal the truth may be close questions for a prosecuting attorney. In deciding whether to press perjury charges, therefore, a prosecutor may be unduly influenced by his desire to attract public attention. ${ }^{127}$

Only one of the contested charges brought by the Watergate Special Prosecution Force rested exclusively on a claim of perjured grand jury testimony. (It may be assumed that prosecutorial overreaching, if any, was confined to charges contested by defendants.) That testimony, by Dwight Chapin, Mr. Nixon's appointment secretary, antedated the creation of the Special Prosecution Force. ${ }^{128}$ Ed Reinecke, former Lieutenant Governor of California, was prosecuted only for perjury, but his false testimony was given in the Senate Judiciary Committee's 1970 hearings on the nomination of Richard Kleindienst as Attorney General. ${ }^{129}$ Neither of these charges even arguably involved a deliberate effort to trap a witness into committing perjury.

This record contrasts with the pattern of the anticommunist investigations of the late 1940's and early 1950's. Apart from the Rosenberg ${ }^{130}$ and Dennis ${ }^{131}$ cases, virtually all other principal prosecutions ${ }^{132}$ were exclusively perjury cases originating with disputed testimony before investigatory bodies. Thus, the risk of over-reliance on perjury charges cannot be overlooked and must induce caution when considering the creation of a permanent special prosecutor. ${ }^{133}$

A second practical consideration that weighs against the creation of a judicially appointed special prosecutor is the need for cooperation between the special prosecutor and the Attorney General. When jurisdiction is based on specified people and events, disputes over the extent of a special prosecutor's jurisdiction can easily arise, drastically

127. See N.Y. Times, July 15,1976 , at 21 , col. 3 (review of grand jury testimony leading to perjury indictment revealed problems of memory due to lapse of time).

128. See generally WATERGATE REPORT, supra note 81, at 50-87.

129. See United States v. Reinecke, 524 F.2d 435 (D.C. Cir. 1975).

130. United States v. Rosenberg, 195 F.2d 583 (2d Cir.), cert. denied, 344 U.S. 838 (1952).

131. United States v. Dennis, 183 F.2d 201 (2d Cir. 1950), aff'd, 341 U.S. 494 (1951).

132. E.g., United States v. Remington, 208 F.2d 567 (2d Cir. 1953), cert. denied, 347 U.S. 913 (1954); United States v. Hiss, 185 F.2d 822 (2d Cir. 1950), cert. denied, 345 U.S. 942 (1953); United States v. Lattimore, 112 F. Supp. 507 (D.D.C. 1953), aff'd in part and rev'd in part, 215 F.2d 847 (D.C. Cir. 1954).

133. See Questions on Nadjari, N.Y. Times, May 26, 1976, at 78, col. 6 (criticism of Special Prosecutor Nadjari for heavy reliance on perjury changes in seemingly peripheral investigations). 
impairing his effectiveness. Often evidence of public criminality is not uncovered until 2 or 3 years after the crime, and additional years may be required to complete an investigation. Jurisdictional disputes between prosecutors could prolong this process, possibly until the statute of limitations would prevent prosecution.

The experience of the Watergate Special Prosecution Force is imstructive. Although its initial mandate was broad, its investigations expanded over $1 \frac{1}{2}$ years into many areas that no one had contemplated. ${ }^{134}$ The Justice Department never indicated any opposition to this expansion of jurisdiction. The Special Prosecutor also required Justice Department cooperation in arranging plea bargains, ${ }^{135} \mathrm{~m}$ inaking voluntary disclosures of wiretaps, ${ }^{136}$ and in fulfilling his obligations under the Jencks Statute ${ }^{137}$ and Brady v. Maryland. ${ }^{138}$

Such harmony is even inore essential if the President is personally implicated in a crimmal investigation, for an incumbent President might exploit disputes between the Justice Department and a special prosecutor in his appeals for popular political support. Froin the time of Cox's dismissal until Richard Nixon's resignation, the Justice Department and the Special Prosecutor were never publicly at odds. Indeed, in the fimal stages of the dispute over the amenability of Mr. Nixon's recordings to a trial subpoena, the Attorney General promised to support the Special Prosecutor's independence. ${ }^{139}$ This support probably contributed to Mr. Nixon's isolation and loss of power. In short, a special prosecutor who can cooperate and work effectively with the executive branch can more effectively investigate the highest political office. Such cooperation is more likely if the special prosecutor is part of that branch and not an outsider.

\section{b. Depoliticization}

The history of major corruption cases indicates that there is no inherent structural impediment to full nonpartisan investigation within the system. Where the tradition of nonpartisanship and independence from the Justice Department is strong, as it was in Buckner's prosecution of Daugherty and Seymour's prosecution of Mitchell and Stans, the

134. Compare the status report of cases in WATERGate REPORT, supra note 81, at 155-70, with the original charter, 38 Fed. Reg. 14,688 (1973).

135. See Appendix at 28-32, 86, United States v. Cowan, 524 F.2d 504 (5th Cir. 1975), cert. denied, 425 U.S. 971 (1976).

136. See, e.g., Affidavit of Jannes L. Quarles, III, at 2-4, United States v. Connally, Cr. No. 74-440 (D.D.C. Nov. 7, 1974).

137. 18 U.S.C. $\$ 3500(b)$ (Supp. V 1975) (requiring production of prior statements by prosecution witnesses).

138. 373 U.S. 83 (1963) (requiring production of exculpatory evideuce).

139. WATERGATE REPORT, supra note 81 , at 15 . 
present system functions admirably. If there is any weakness in the ability of the Justice Department to investigate the executive branch, it is attributable not to the Department's structure, but to its staffing.

Of course, a full and fair investigation of the President, should it ever be required again, may not be attainable within the present structure. A United States attorney who attempted to conduct an investigation of the White House would probably be removed by the President. His removal under such circumstances, however, would probably trigger a repetition of the institutional changes that led to the creation of the Watergate Special Prosecution Force. Even when Congress is politically aligned with the President, as it was not during the Watergate crisis, such circumstances could generate sufficient public support to enable a special prosecutor to function freely. President Harding, for example, in a far less provocative situation than Watergate, could not prevent a Republican Congress from conducting a debilitating investigation of his administration. ${ }^{140}$

The focus, however, should not be on the presumably rare case of Presidential criminality, but on the more frequent cases of possible wrongdoing by subordmates, especially those in the law enforcement chain-of-command. The Justice Department is traditionally a repository of high-level patronage positions ${ }^{141}$ readily available to those who have played prominent roles in political campaigns. Only by contrast to the President himself do others in the law enforcement chain-of-command appear to be minor officials. United States attorneys and their surrogates are extremely powerful people with virtually unfettered discretion to alter drastically the lives of those they investigate. The problem is that the conduct of such officials, who but occasionally-and then temporarily-receive any public attention, is invariably investigated by their peers, ${ }^{142}$ whose political interests often coincide with their own. Two possible means of removing this blatant partisan factor from federal law enforceinent are discussed below.

$i$. Use of the Advice and Consent Power. The Constitution requires the advice and consent of the Senate for certain Presidential appointments. ${ }^{143}$ Under the present statutory scheme confirmation is required for the Attorney General, his Deputy, the Solicitor General, Assistant Attorneys General, the Director of the Federal Bureau of

140. See text accompanying note 93 supra.

141. By way of contrast, Great Britain removed partisan factors from the selection of law enforcement personnel at least 50 years ago. See Gemmill, What Is Wrong With the Administration of Our Criminal Laws? 4 J. CrIM. L. \& Criminolooy 698, 700 (1914).

142. See text accompanying notes 59-69 supra.

143. See text accompanying note 6 supra. 
Investigation, United States attorneys, and United States Marshals. ${ }^{\mathbf{1 4 4}}$ Theoretically, the Senate could use this power to assure that high-level positions in the Justice Department are filled only by persons who can be expected to enforce the law unfettered by partisan concerns; indeed, the origins of the clause would support such a use.

During the Constitutional Convention, one faction feared that unchecked executive appointunent power would lead to inonarchy, while another argued that purely executive appointnients would result in better qualified appointees. ${ }^{145}$ The advice and consent clause represented a conipromise between these groups. Alexander Hamilton, a proponent of unfettered executive appointment power, stated that there was no real compromise since "every advantage to be expected froin such an arrangement would in substance be derived fron the power of nomination .... There can in this view be no difference between nominating and appointimg."148 Yet Hamilton also stated that the purpose of requiring Senate cooperation was (1) to check Presidential favoritism; (2) to prevent both the appoimtment of unfit characters and appoimtments inade for the President's personal gain or because of fanily connections; and (3) to stabilize each administration. ${ }^{147}$ Certainly the appointment of political advisors and supporters could be deemed an act of Presidential favoritism and in furtherance of the President's narrow political interests. The Senate could therefore further the historical purposes of the advice and consent clause by refusing to approve a partisan nominee. For nearly 200 years, however, the Senate-itself a preeminently partisan body - has failed to einploy the clause in this inanner.

Its use of the clause has varied depending on the type of office involved. In approving cabinet nominees, it has virtually abandoned its constitutional powers, refusing to confirm only 8 im 188 years. ${ }^{148}$ By

144. 28 U.S.C. $\S \S 503$ (Attorney General); 504 (Deputy Attorney General); 505 (Solicitor General); 506 (Assistant Attorneys General); 541 (United States attorneys); 561 (United States Marshals) (1970); 28 U.S.C.A. \$ 532 note (Omnibus Crime Control and Safe Streets Act of 1968, Pub. L. No. 90-351, Title VI, § 1101, 82 Stat. 197, 236) (transferring the power to appoint the Director of the Federal Bureau of Investigation from the Attorney General to the President, by and with the advice and consent of the Senate) (Supp. 1976).

145. J. Harris, The Advice and Consent of the Senate 17-35 (1953) [hereinafter cited as J. HARRIs].

146. The Federalist No. 76, at 512 (A. Hamilton) (J. Cooke ed. 1961).

147. Id. at 513.

148. The Senate's rejection of Roger Taney as Secretary of the Treasury reflected a violent disagreement with President Jackson over the creation of a national bank. Four nominees of President Tyler were rejected: Tyler, a "Democrat turned Whig," succeeded President Harrison upon his death and was confronted with a stridently partisan Democratic Congress. The refusal to confirm Heury Stanbery, who was renominated as Attorney General after he resigned to defend President Andrew Johnson in the impeachment proceedings, stemmed from the Senate's antipathy toward Johnson. Only 2 rejections have occurred in the last 108 years. When Charles Warren was not 
contrast, it has virtually usurped the appointment power over United States District Judges and to lesser extent, over United States attorneys. Senators of the President's party from the states where judicial appointments are to be made have traditionally wielded a veto power prompted by concerns infinitely removed from those suggested by Hamilton. An unexplained declaration that the President's nominee is "personally obnoxious" to such a Senator can usually defeat his appointment. ${ }^{140}$ Furthermore, many appointments to the federal judiciary originate with a Senator's suggestion. ${ }^{150}$ The Senate's treatment of Presidential noininations to the Supreme Court has varied greatly. About one-fourth of the nominations subinitted before 1894 were rejected; all but 1 of 44 nominations made between 1894 and 1968 were confirmed. ${ }^{161}$ Then in slightly over 2 years the Senate forced President Johnson to withdraw his nomination of Justice Fortas as Chief Justice ${ }^{162}$ and rejected President Nixon's nommations of Judges Haynesworth and Carswell. ${ }^{153}$

Neither Presidents nor Senators appear consistently as heroes or villains in this history. Few of the 20 Supreme Court rejections between 1789 and 1894 were predicated on the unfitness of the nominee. ${ }^{154}$ Yet im some imstances when Senators have insisted on the right to select their respective states' federal judges, their choices have appeared superior to those of the Presidents. ${ }^{165}$ The traditional independ-

confirmed as Attorney General in 1925, some question was raised about a possible conflict of interest with the Sugar Trust; but his rejection was more likely a wanton exercise of Congressional muscle in the wake of the Teapot Dome scandal. See J. Harrus, supra note 145, at 259-60; Jaines, Senatorial Rejections of Presidential Nominations to the Cabinet: A Study in Constitutional Custom, 3 ARIz. L. REv. 232 (1961). Lewis Strauss, nominated to be Secretary of Commerce in 1959, had made powerful enemies in his career, and his laineduck appointment was rejected by a heavily Democratic Senate. See H. PARMet, EISENhower AND THe AMERICAN CRUSAdes 542-45 (1972).

149. J. HARRIS, supra note 145 , at 217.

150. The administrative assistant to former Senator James Buckley of New York publicly "advised" Buckley's successor, Daniel P. Moynihan, "[Y]ou are not a great dispenser of patronage. . . . Your main appointments are Senate pages . . and the Federal bench." N.Y. Times, Nov. 17, 1976, at A31, col. 2.

151. J. HARRIs, supra note 145 , at 303.

152. N.Y. Times, Oct. 3, 1968, at 1, col. 8.

153. Id., Apr. 9, 1970, at 1, col. 8.

154. Joseph Harris concluded that only 4 of the 20 rejections were predicatcd on the nominee's lack of fitness; the remainder were based on strictly partisan concerns. J. HARRIS, supra note 145, at 303 (citing C. WARREN, THE SUPREME COURT IN UNITED StaTES History 110-19, 757-63 (1928 ed.)).

155. See J. HARrIs, supra note 145, at 321-24, describing the dispute between President Truman and Senator Douglas of Illinois over two district court appointments. Truman's selections were made without consulting Douglas, who was then Illinois' only Democratic Senator. Douglas' choices appeared to have been better qualified. In the Senate debate Douglas refused to assert that Truman's nominees were "personally obnoxious"; rather, he said that the manner of their nomination was obnoxious. The Senate refused to confirm the President's nominees. 
ence of United States attorneys in some districts is also a product of senatorial influence. ${ }^{156}$

President Carter has established a merit system for selectimg federal appellate judges, but has left intact the traditional method for choosing District Judges-a method that confers considerable power on local party leaders. ${ }^{157}$ Attorney General Bell is reportedly "committed to a merit selection process for appointing U.S. attorneys and federal judges but will continue to give Democratic senators a major voice in choosing thein."158 Whether this approach will substantially alter the existing system remains to be seen. New York's new Democratic Senator, Daniel Moynihan, recently took an extraordmary and laudable step by announcing that he would recommend retention of three incumbent United States attorneys, all appointees of a Republican President. Moynihan expressly disapproved the practice of choosing United States attorneys on the basis of party loyalty. ${ }^{159}$ As yet, no other Senator has followed his lead.

Historically, the advice and consent power has been whatever the Senate has made it. It could be a powerful instrument of reform. A Senate resolution urging the President not to allow partisan considerations to influence the selection of law enforcement officials would yield desirable results if its policy were enforced in the confirmation process. Collective senatorial action toward nonpartisan Attorney General nominees is unlikely, however, if the price is forfeiture by individual Senators of their historical patronage power over the federal bench. ${ }^{160}$ A commitment to merit selection without regard to political connections would obviously reduce the personal discretion of individual Senators and thus curtail their power. Yet it also would endow the Senate with genuine power in the selection of at least one cabinet nember.

ii. Consolidation of the Appointment Power. The diffusion of the appointment power would be the best guarantee against its abuse. This could readily be accomplished by the vigilant exercise of the Senate's advice and consent power, as discussed above. But if that development is unlikely, Congress might consider placing the appointunent power largely in nonpartisan hands.

156. See generally Seymour, The Best Public Law Job in the Nation, 25 RECORD of N.Y.C.B.A. 242 (1970).

157. See text accompanying note 149 supra.

158. Washington Post, Feb. 11, 1977, at A2, col. 6.

159. N.Y. Times, Jan. 19, 1977, at 1, col. 4. For a favorable editorial about Moynihan's position, see id., Jan. 20,1977 , at 36 , col. 1 . According to the January 20 account, if candidates were otherwise equally qualified, Senator Moynihan favored the appointment of Democrats once the incumbent United States attorneys' terms had expired. This seems to be a slight retreat from the principle of nonpartisanship.

160. Senatorial courtesy has been traced back to the first year of Washington's presidency. See J. Kallenbach, The American Chief Executtve 394 (1966). 
When the first Congress authorized the appointment of an Attorney General, it required that he be a "meet person, learned in the law."101 Presumably, the constitutional power that allowed Congress to establish this requirement would also permit it to require that the Attorney General lack any marked partisan connection. Such a restriction of the President's appointment power would not preclude the selection of a person who shares his political philosophy. The President would lose, however, the security of knowing that his Attorney General is intimately concerned with his political future and that of his party. It is unlikely that such a deprivation constitutes an unconstitutional infringement on Presidential powers. ${ }^{182}$ In addition, the Congress could vest in the Attorney General the power to appoint his Deputy and all other subordinate officials in the Justice Department. ${ }^{163}$ To further the purpose of depoliticization, the Senate might seek to obtain from a prospective Attorney General a commitment to make such appointments on a nonpartisan basis, without allowing pressures from either the White House or Congress to override his judgment as to competence.

There are two difficulties with this alternative: first, the political obstacle that the same factors that make the Senate's piecemeal abandonment of its patronage powers unlikely if appointment power is left in the President, ${ }^{104}$ make unlikely their abandonment in a single legislative package; and second, the risk that an Attorney General's partisan temperament will reveal itself after his appoimtment, or that he will be weak and subject to Presidential control. By hypothesis, the Senate would then be unable to check his appointment power.

\section{c. Partial Depoliticization}

Legislation introduced in the 94th Congress attempted to deal with the problem of the executive branch investigating itself by reorganizing the Justice Department. A 1976 version of the Watergate Reorganization and Reform Act would have created a Division of Government Crimes in the Department and established a procedure for appointing a temporary special prosecutor. ${ }^{165}$ The Senate adopted a substitute version reported by the Judiciary Committee, ${ }^{186}$ which had largely adopted President Ford's suggestions for a permanent special prosecutor. ${ }^{107}$ The

161. See text accompanying note 7 supra.

162. See Myers v. United States, 272 U.S. 52, $264-74$ (1926) (Brandeis, J., dissenting). The opinion summarizes laws governing Presidential appointments, and sets out laws that have required selections on a nonpartisan basis. Id. at 275 n.52.

163. See text accompanying note 6 supra.

164. See text accompanying note 160 supra.

165. S. 495, 94th Cong., 2d Sess. (1976).

166. 122 CoNg. REc. S12076-78, S12103, S12112 (daily ed. July 21, 1976).

167. See 122 CONG. REC. S12078-79 (daily ed. July 21, 1976) (remarks of Senator Ribicoff); letter from the President to the Speaker of the House of Representatives 
Senate bill would have provided for appointment by the President, with the advice and consent of the Senate, of a special prosecutor for a single 3-year term. ${ }^{108}$ The special prosecutor could be removed by the President only for "extraordinary improprieties, for malfeasance in office, or for any conduct constitutimg a felony." "He could not have held a high-level position in any organization working on behalf of a candidate for federal office in the 5 years preceding his appointment. ${ }^{170} \mathrm{He}$ would have jurisdiction to investigate and prosecute possible violations of law by the President, Vice President, Attorney General, or Director of the FBI; inembers of Congress; federal judges; and other high level executive officials. ${ }^{171}$ The bill would also have established an Office of Government Crimes within the Justice Department, headed by a Director with the same qualifications as the special prosecutor, who would report directly to the Attorney General. ${ }^{172}$ Certain types of politically weighted criminal matters would be delegated to the Office of Government Crimes. ${ }^{173}$ The bill did not reach the floor of the House of Representatives.

Such a bill looks to the Watergate experience and attenpts to institutionalize guarantees that, should history repeat itself, the Justice Department would conduct a fair self-investigation. Unfortunately, this type of reforin is directed at the precise problem that the present system has proved itself most able to handle. This criticisin is not dispositive, however, since it overlooks the extent to which the Democratic Congress contributed to the successful prosecution of the Watergate criminals. ${ }^{174}$

and the President of the Senate, reprinted in 122 Cong. REc. S12085-91 (daily ed. July 21,1976 ).

168. S. 495 , \& 591(a)-(b), 94th Cong., 2d Sess.; 92 Cong. REC. S12076 (daily ed. July 21,1976$)$.

169. Id. § $591(\mathrm{~d})$.

170. $1 d$. $\& 591(\mathrm{c})$.

171. Id. $\$ 592$ (a) (1); 92 Cong. REC. S12077 (daily ed. July 21, 1976).

172. $1 d . \& 594$.

173. Id. \& 595 .

174. See text accompanying notes 92-95 supra. See also letter from Professor Philip B. Kurland to Senators Ribicoff and Percy (July 8, 1976), reprinted in 122 CoNG. REC. S12082-83 (daily ed. July 21, 1976), rejecting the notion that the Watergate Special Prosecutor contributed to the discovery and punishment of Watergate abuses. Kurland assigns all credit to the Senate Select Committee, the House Judiciary Committee, and the press.

Professor Kurland goes too far. Neither the Senate Select Committee nor the House Judiciary Committee obtained any Presidential tape recordings on its own. The Senate Select Committee failed in its effort (Senate Select Committee v. Nixon, 366 F. Supp. 51 (D.D.C. 1973)), and the House Judiciary, rather than attempting to enforce its subpoena, chose to predicate an Article of Impeachment on Mr. Nixon's failure to comply with it. The Article carried by an almost party-line vote, 21-17. N.Y. Times, July 31, 1974, at 1, col. 8. By contrast, Articles of Impeachment based on the contents of the recordings carried by larger and bipartisan majorities. Id., July 28,1974 , at 1 , col. 8 ; id., July 30,1974 , at 1 , col. 8 . Once Nixon was forced to produce 
More importantly, the Senate Bill sought more to accommodate concern over political influences than to confront the basic structural problems of a politicized Justice Department; proposed reform is limited to a nonpartisan special prosecutor and an Office of Government Crimes.

This approach is unsatisfactory for three reasons. First, as discussed above, problems emerge when jurisdiction is defined in terms of people and events. ${ }^{175}$ Second, the existence of "nonpartisan" enclaves within the Justice Department is likely to have undesirable administrative side effects. It would permit the appointment of strident partisans to other positions in the Department. Those responsible for middle level appointments within the Department could point both to the withdrawal of politically sensitive cases from the rest of the Department and to the nonpartisan special prosecutor as a justification for partisan appointments to the remaining, and more numerous, positions. Morale, recruitment, and the stability of the professional staff all would suffer, since one of the rewarding aspects of work in the Department is the commitment to professional law enforceinent objectives rather than partisan advantage. The approach of the 1976 bill would also invite end-runs around the one or two nonpartisan components of the Department by more partisan colleagues. Third, law enforcement cannot legitimately be divided into partisan and nonpartisan components. This is true practically as well as philosophically. Some of the most important cases dealing with inajor corruption start at the lowest levelswhich, even under the 1976 bill, might continue to be staffed by partisan prosecutors. Yet in order to investigate thoroughly, these prosecutors must be able to obtain the confidence of those whom they investigate. It would be difficult to instill that confidence if only the nonpartisan branch of law enforcement was generally believed to be committed to vigorous, impartial prosecution.

Apart from these practical considerations, a statute that divides the Justice Department into partisan and nonpartisan components is an ugly vulgarization of the ideal of equal justice under law. For some the scales of justice will be balanced solely by facts; for others, by both facts and an institutionally legitimized partisan prejudice. If this is "Watergate Reform," we are better off without it.

\footnotetext{
the tape recording of his June 23, 1972, conversation with H.R. Haldeman, all of the opposition to at least one Article of Impeachment disappeared. 1d., Aug. 7, 1974, at 1, col. 5. The ability of the Special Prosecution Force to obtain this evidence, upon which the bipartisan coalition for impeachment was built, was therefore critical in the process. The press, public opinion, and Congress all contributed to the creation of the Special Prosecution Force. See text accompanying notes 92-100 supra. No single institution can be credited with full responsibility for the end result; nor can the importance of any be discounted.
}

175. See text accompanying notes 120-35 supra. 
II

\section{State Governments}

\section{A. Introduction}

State government structures differ not only from the federal government model, but among themselves as well. The general structure of federal executive power is a pyramid, with the President at the top. In state governments law enforcement functions are generally shared by the Governor, the Attorney General and the local prosecutors, usually called district attorneys. ${ }^{176}$ The individual law enforcement systems vary widely, ${ }^{177}$ but a few common characteristics may be noted.

Governors, of course, are elected in each state. State attorneys general, im almost all cases occupants of a constitutional rather than a statutory office, ${ }^{178}$ are elected in about 40 states and in the rest are appointed, either by the Governor, by the state supreme court (Tennessee), or by the legislature (Mame). ${ }^{179}$ Since there was no local prosecutor at common law, ${ }^{180}$ the attorney general in a common law jurisdiction has power to initiate criminal prosecutions. ${ }^{181}$ In varying degrees the attorney general's common law powers of prosecution have been transferred to district attorneys either by constitution or by statute. ${ }^{182}$

Perhaps because "the colonists preferred local control of this important role in government," ${ }^{183}$ the most significant figure in state law enforcement is the district attorney, who occupies "a characteristically American office." ${ }^{184}$ District attorneys are elected in almost all states ${ }^{185}$

176. See note 3 supra.

177. See Committee on the Office of Attorney General, National Association of Attorneys General, Report on the Office of Attorney General, Table 2.3, at 28 (1970) (powers of attorneys general to initiate prosecutions) [hereinafter cited as NAAG REPORT]; id., Table 2.4, at 133 (powers in proceedings initiated by local prosecutors); id., Table 2.6, at 144 (role in appeals). See also Pitler, Superseding the District Attorneys in New York City-The Constitutionality and Legality of Executive Order No. 55, 41 FordhaM L. Rev. 517 (1973); Nadjari, New York State's Office of the Special Prosecutor: A Creation Born of Necessity, 2 Hofstra L. Rev. 97 (1974).

178. See NAAG REPORT, supra note 177, Table 1.211, at 24 (legal bases of the various state Attorneys Generals' offices).

179. Id., Table 1.41 , at 63 .

180. Id. at 51 .

181. See, e.g., State v. Finch, 128 Kan. 665, 280 P. 910 (1929); People v. Kramer, 33 Misc. 209, 212, 68 N.Y.S. 383, 386 (N.Y. County Ct. Gen. Sess. 1900).

182. NAAG REPORT, supra note 177, at 103-36. See id., Table 1.331, at 39; id., Table 2.3, at 128 .

183. P. Weston \& K. Welis, Criminal Justice 205 (1976).

184. NAAG REPORT, supra note 177 , at 103.

185. Id., Table 2.13, at 106-07. In Connecticut local prosecutors are selected by judges of Connecticut's Superior Court. CoNN. GEN. STAT. ANN. § 51-278 (West Supp. 1977). Although this type of selection would raise serious constitutional issues if employed in the federal system (see text accompanying notes 93-115 supra), federal sep- 
and have the general power to enforce criminal laws. ${ }^{186}$ The number of assistants in a particular district attorney's office inay vary from none to several hundred. ${ }^{187}$ Party ties are sometimes important in small offices and in filling top positions in larger offices. ${ }^{188}$

\section{B. Effectiveness of Present Systems}

A review of criminal cases brought against state law enforcement officials demonstrates that although the state systems cannot monitor themselves at the highest levels, they at least contain mechanisms for thorough self-investigation at lower levels. In the past 10 years six Governors or former Governors have been charged with criminal conduct during their tenure as Governor; all of these charges were brought in federal court by the local United States attorney's office. ${ }^{180}$ That

aration-of-powers principles have been found inapplicable to the states. See Prentis v. Atlantic Coast Line Co., 211 U.S. 210, 225 (1908) (Holmes, J.); Dreyer v. Illinois, 187 U.S. 71, 83-84 (1902) (Harlan, J.). Thus, theoretically at least, states would be free to adopt the criminal procedures of the civil law countries. See J. Merryman, The Crvil LaW Tradition 136-39 (1969). The Connecticut courts have upheld that state's statutory scheme, mainly on the ground that it has always been done that way. State v. Luban, 28 Conn. Supp. 366, 263 A.2d 87 (Super. Ct. 1970); State v. DiLeo, 28 Conn. Supp. 354, 261 A.2d 547 (Super. Ct. 1969); State v. Mazzadra, 28 Conn. Supp. 252, 258 A.2d 310 (Super. Ct. 1969).

The issue of executive versus judicial exercise of prosecutorial power must be distinguished from issues raised by the delegation to the public of the power to initiate criminal proceedings. See, e.g., CAL. Pen 1 L CODE $\$ 1427$ (a) (Deering Supp. 1976); Wis. STAT. ANN. § 968.02(3) (West 1971). Such delegation has been found unconstitutional in California on the ground that it violates the provision vesting executive authority within the state. People v. Municipal Court (Pellegrino), 27 Cal. App. 3d 193, 20607, 103 Cal. Rptr. 645, 655-56 (2d Dist. 1972).

186. See, e.g., CaL. Gov't Code $\S \S 26500-01$ (West 1968); Wis. Stat. ANn. $\S \S$ 59.47(1)-47(2) (West 1957 \& Supp. 1976).

187. National District Attorneys Associntions, Report on Proceedings, supra note 3 , Chart I, at 41 .

188. In California "the top assistants are personal appointees of the district attorney, often close political associates who helped in his campaign for office. Other deputies are under civil service in merit system counties." B. CoOK, THE JUdicinL Process IN CALIForNiA 88 (1967). For a description of a comparable approach to the appointment of assistant United States attorneys, see N.Y. Times, Nov. 17, 1976, at A14, col. 1.

189. Vice President Spiro Agnew pled nolo contendere to a federal tax evasion charge predicated on moneys reeeived pursuant to arrangements made while he was County Executive and Governor of Maryland. See note 73 supra. Former Governor William Wallace Barron of West Virginia pled guilty to bribing the foreman of a federal petit jury that had acquitted him of bribery charges. N.Y. Times, Mar. 30, 1971, at 16, col. 3. Governor David Hall of Oklahoma was convicted on federal extortion and bribery charges, id., Mar. 7, 1975, at 14, col. 3; id., Mar. 15, 1975, at 1, col. 3. Former Governor Kerner of Illinois was convicted (while a judge on the United States Court of Appeals for the Seventh Circuit) for federal offenses related to his conduct as Governor. United States v. Isaaes, 493 F.2d 1124 (7th Cir.), cert. denied, 417 U.S. 976 (1974). Governor Marvin Mandel of Maryland prevailed on a motion for a mistrial on federal charges arising out of his activities as Governor. N.Y. Times, Dec. 9, 1976, at 18 , col. 3. Former Governor Arch Moore of West Virginia was acquitted of federal 
none of these cases was terminated by a court ${ }^{100}$-indeed only one ended in an acquittal ${ }^{191}$ - would seem to indicate that the charges were not products of overzealousness. On the other hand, prosecutions directed against local prosecutors often take place in state courts. ${ }^{102}$ When a district attorney ${ }^{193}$ or someone connected with him $^{194}$ is implicated, special prosecutors are often appointed. In some cases district attorneys are transferred from one county to another; this procedure is often directed by a Governor pursuant to a specific statutory authority. ${ }^{195}$

\section{Prosecuting Governors}

The demonstrated inability of local law enforceinent officers to deal with high-level executive corruption in state government is troublesome, primarily because it implies serious limitations in the state administration of justice. It also suggests, at first glance, that there is corruption within the federal government going undetected because of the absence of an outside prosecutor to discover it. The failure of district attorneys successfully to prosecute Governors and their associates, however, is largely explained by disadvantages peculiar to their positions.

A United States attorney generally has jurisdiction over much larger areas than a district attorney. No Umited States attorney's office covers more than one state, but each covers a significant part of a state, invariably several counties; $;^{196}$ and their subpoena power is national in

extortion charges based on conduct as Governor. Id., May 6, 1976, at 1, col. 2; see United States v. Moore, 405 F. Supp. 771 (S.D.W. Va. 1976).

190. For a description of the judicial dismissal of an indictment for insufficiency, see N.Y. Times, Apr. 27, 1977, at 70, col. 1. See also F.R. CRMM. P. 29(a), empowering a judge to enter a judgment of acquittal where the evidence is found insufficient to sustain a guilty verdict.

191. See note 189 supra (Governor Moore).

192. See cases cited in note 193 infra. See also N.Y. Times, Feb. 27, 1977, \$ 4, at 6, col. 3. But see id., May 22, 1976, at 1, col. 4 (former district attorney convicted in federal court for a billing fraud during his incumbency).

193. See Weems v. Anderson, 257 Ark. 376, 516 S.W.2d 895 (1974); People ex rel. Lindsley v. District Court, 29 Colo. 5, 12-17, 66 P. 896, 898-99 (1901); People v. Sears, 49 Ill. 2d 14, 273 N.E.2d 380 (1971); Williams v. State, 188 Ind. 283, 123 N.E. 209 (1919); Northcutt v. Howard, 279 Ky. 219, 130 S.W.2d 70 (1939); State ex rel. Thomas v. Henderson, 123 Ohio St. 474, 175 N.E. 865 (1931); Commonwealth v. Ryan, $126 \mathrm{~Pa}$. Super. Ct. 306, 188 A. 764 (1936); State v. Wallace, 119 Wash. 457, 206 P. 27 (1922); State ex rel. Matko v. Ziegler, 154 W. Va. 872, 179 S.E.2d 735 (1971). See also N.Y. Times, July 24, 1976, at 27, col. 1.

For a discussion of the power of trial courts to appoint special prosecutors, see Note, The Special Prosecutor in the Federal System: A Proposal, 11 AM. Crim. L. REv. 577, 580-82 (1973); Note, Special Investigating Grand Jury, 111 U. PA. L. REv. 954, 968-70 (1963).

194. See State v. Hayes, 127 Conn. 543, 18 A.2d 895 (1941); State ex rel. Williams v. Ellis, 184 Ind. 307, 112 N.E. 98 (1916) (district attorney publicly affirned innocence of deputy under investigation).

195. See, e.g., Austin v. State ex rel. Christian, 310 So. $2 d 289$ (Fla. 1975).

196. 28 U.S.C. $\S \S 81-131,541$ (1970). 
scope without any procedural burdens whatsoever. ${ }^{107}$ Neither state nor county lines pose serious limitations for a federal criminal investigation. A district attorney, however, is usually limited to prosecuting crimes occurring within county lines, and his subpoena power usually does not extend beyond his state. ${ }^{108}$ Since many state capitals are small cities, the district attorney who has jurisdiction over criminal acts by state officials may have a small staff that cannot adequately handle a corruption case. Also, United States attorneys' offices generally have more experience with complex cases.

Similarly, that a district attorney has been elected within the state, ${ }^{199}$ either as part of the Governor's ticket or in opposition to it, may be a constraming factor. A district attorney's power is also subject to far greater control within the state than is that of a United Staes attorney. The state attorney general may intervene in his cases, ${ }^{200}$ or the Governor may replace him. ${ }^{201}$ The diffusion of the district attorney's power significantly impedes his ability to undertake investigations within state government.

The effect of this diffusion is magnified by a consideration of the mechanics of a corruption prosecution. It is rare, if not unconceivable, that corrupt activities in a Governor's mansion occur in the presence of witnesses who are themselves innocent of wrongdoing. Such a case therefore invariably requires the cooperation of a person who has been closely associated with the subject of the inquiry. ${ }^{202}$ It is extremely unlikely, however, that a Governor's close associate will plea bargain with a prosecutor whose powers can be substantially curtailed by the Governor or his successor. ${ }^{203}$ Even if political pressures would prevent the Governor from interfering, a witness who perceives a possibility of such interference will hesitate to come forward. The problem with state

197. FED. R. CRIM. P. 17(e)(1) provides for subpoena service anywhere in the United States.

198. See, e.g., Wis. Stat. ANn. \& 885.01(2) (West 1966).

199. See generally NAAG REPORT, supra note 177, Table 2.13, at 106.

200. See generally id., Table 2.4, at 133-34.

201. See Pitler, supra note 177 , at 518-22, 526-45.

202. See, e.g., United States v. Isaacs, 493 F.2d 1124 (7th Cir.), cert. denied, 417 U.S. 976 (1974) (illustrating cooperative witnesses in the Otto Kerner case); R. CoHEN \& J. WITCOVER, supra note 73 , at $52-96,113-36$ (illustrating cooperating witnesses in the Spiro Agnew case).

203. An analogy might be drawn to a United States attorney's investigation of high-level federal officials. The United States attorney, of course, can be removed at the whim of the President. 28 U.S.C. $\$ 541$ (e) (1968). John Dean was not inhibited by this particular concern even though the danger of behind-the-scenes contact between the investigator and the Chief Executive did in fact materialize. See notes 75-76 supra and accompanying text. The intermediary was Henry Petersen, a Democrat appointed by Mr. Nixon. See note 38 supra and accompanying text. It is hoped that in a strictly nonpartisan Justice Department even such communications would be inhibited. 
law enforcement systems, therefore, is not a lack of will power but of muscle.

Congress, however, has used its regulatory power over interstate commerce and the mail to bring most local corruption within the reach of federal statutes. ${ }^{204}$ This expansion of federal power into basically local matters accentuates the need to depoliticize federal law enforcement, in order to insure nonpartisan investigation of state officials.

\section{Special Prosecutors}

When local district attorneys are accused of crime, judges frequent1y appoint special prosecutors to allow objective investigations. ${ }^{205}$ Such an appointment may raise two constitutional issues. First, it may violate separation of powers provisions of state constitutions. ${ }^{206} \mathrm{Sec}-$ ond, any relationship between the appointing judge and the special prosecutor suggests that the proceedings may violate due process.

In Smith v. Gallagher ${ }^{207}$ the trial court convened a special grand jury and appointed a special prosecutor in response to a citizen's petition alleging that the local district attorney was unable or unwilling to attack widespread corruption in Philadelphia. The Pennsylvania Supreme Court held the appoimtment orders invalid, principally as a violation of the separation of powers. ${ }^{208}$ Judge Musmanno, for the majority, stressed that the special prosecutor was free from the restraints incident to a structured government position:

[He] would not be answerable to anyone for misbehavior or usurpations. Not holding a constitutional office he would not be subject to impeachment; being clothed with judicial sanction he would be immune from criminal prosecution; engaged in governmental busimess he could not be sued civilly. No person in the United States nray constitutionally wear such impenetrable armour against responsibility for possible illegal perforniance. ${ }^{209}$

204. See 18 U.S.C. $\$ \$ 1341,1951,1952$ (1970). See also United States v. Archer, 486 F.2d 670 (2d Cir. 1973) (overreaching by federal prosecutors in prosecution of local officials); United States v. Kenny, 462 F.2d 1205 (3d Cir.), cert. denied, 409 U.S. 914 (1972); United States v. DeSapio, 435 F.2d 272 (2d Cir. 1970), cert. denied, 402 U.S. 999 (1971).

205. See note 193 supra and accompanying text.

206. See, e.g., CAL. CoNST. art. 3, § 1; In re Richardson, 247 N.Y. 401,160 N.E. 655 (1928) (Cardozo, C.J.) (holding nnconstitutional a state law authorizing the Governor to appoint a Supreme Court Justice to investigate allegations of corruption against a public official). Federal separation of powers principles do not apply to state governments. Prentis v. Atlantic Coastline, 211 U.S. 210, 225 (1908) (Holmes, J.); Dreyer v. Illinois, 187 U.S. 71, 83-84 (1902) (Harlan, J.).

207. 408 Pa. 551, 185 A.2d 135 (1962).

208. Judge Musmanno also found the appointment of the special prosecutor an uneonstitutional invasion of the people's right to select a district attorney of their choice. ld. at 583, $185 \mathrm{~A} .2 \mathrm{~d}$ at 151 .

209. Id. at $581,185 \mathrm{~A} .2 \mathrm{~d}$ at 150 . 
Judge Musmanno neglected to discuss the court's extraordinary powers to control any prosecutor's behavior by finding him in contempt of court or by ordering the dismissal of charges. ${ }^{210}$ The issue is whether state constitutions permit prosecutions by officers answerable only to the judicial branch. The added increment of risk that a special prosecutor will behave irresponsibly ${ }^{211}$ when subject only to judicial authority and not to other controls must be balanced against the public need for his efforts. If the allegations of the petition that triggered the special prosecutor's appointment in Smith were true, the special prosecutor could provide a tremendous social benefit; the allegations could only be tested if the special prosecutor carried out his mandate. History does not suggest that a special prosecutor whose power derives from judicial rather than executive authority is more likely to abuse his power. ${ }^{212}$ Thus Smith v. Gallagher is a somewhat unrealistic exposition of the evils of a judicially appointed special prosecutor.

Judicial appointment of a special prosecutor could conceivably violate due process by destroying the objective detachment of the court froin the prosecutor. When judicial involvement in the prosecution begins and ends with the appointment itself, it is hardly arguable that the organic link between prosecutor and judge violates a defendant's rights. If, however, the appointing judge begims to take an active role in the prosecution, a substantial due process concern would be presented. ${ }^{213}$ No case has been found, however, where actual judicial involve-

210. See, e.g., United States v. Cox, 342 F.2d 167 (5th Cir.), cert. denied, 381 U.S. 935 (1965); text accompanying note 200 infra. See also United States v. Means, 513 F.2d 1329 (8th Cir. 1975).

211. In a footnote Judge Musmanno said, "[T]here is no indication, and it is not suggested, that [the special prosecutor], who is an estimable member of the bar, would consciously lend himself to the infringement of the rights of others. . ." $408 \mathrm{~Pa}$. at $581 \mathrm{n} .12,185$ A.2d at 150 n. 12 .

212. The author has uncovered no record of blatant abuse of power by a judicially appointed special prosecutor. Recent and vociferous allegations of abuse, however, have been directed against Maurice H. Nadjari, a special prosecutor appointed in New York State by the attorney general pursuant to a gubernatorial request. N.Y. Times, Dec. 23, 1976, at 46, col. 1; id., Nov. 19, 1976, at 1, col. 3; id., July 15, 1976, at 21, col. 3; id., June 16, 1976, at 34, col. 1; id., June 4, 1976, at 1, col. 1; id., May 26, 1976, at 78, col. 6; id., Dec. 3, 1975, at 1, col. 1; id., Oct. 6, 1975, at 1, col. 6.

A full and fair evaluation of Nadjari's record must await resolution of current litigations and will itself be a lengthy matter. Many of the problems involved in the controversy are attributable to Nadjari's vague mandate: to investigate corruption in the criminal justice system. The vagueness of the job is also one reason for opposing a permanent special prosecutor at the federal level. See text accoinpanying notes 122.33 supra. Any possible abuses of power by Nadjari do not reflect on the conventional judicially appointed special prosecutor, whose inandate is invariably much inore limited.

213. Cf. In re Ohver, 333 U.S. 257, 278-79 (1948) (Rutledge, J., concurring) (combining historically separate powers in a single official). 
ment after the appointment of a special prosecutor raised serious due process claims. ${ }^{214}$

\section{Summary}

The inability of state governments to deal with corruption at their highest levels cannot be taken lightly. It erodes confidence in local government, reinforces the propensity to rely on the federal government for solutions, and taxes federal prosecutors who have enough responsibilities without becoming involved in local corruption cases. If the problem is one of power and not of inclination, then local district attorneys should be strengthened, both by increased budgets that will attract and keep experienced attorneys, and by statewide jurisdiction in certain cases. Of course, the diffusion of executive power inherently impedes the development of prosecutorial capability. This impediment could be partially overcome if the office of district attorney were regularly filled by a person whose commitment to law enforcement is deeper than the desire to launch a political career. A district attorney who has served for several years and earned professional respect may develop sufficient stature so that the institutionalized checks on his powers cannot interfere with important investigations. This route is not without dangers, however, as shown by the history of the FBI under J. Edgar Hoover. ${ }^{215}$

At the local level, the appointment of an uninvolved and usually well-respected attorney as a special prosecutor to conduct the investigation and trial of a district attorney has worked fairly well. The general practice of allowing a district attorney under investigation or indictment to perform his usual functions in other matters ${ }^{216}$ may be ill advised. ${ }^{217}$

214. One case does treat the issue of judicial control of a special prosecutor. In People v. Sears, 49 Ill. 2d 14, 273 N.E.2d 380 (1971), a special prosecutor was appointed to investigate possible criminal involvement of the state's attorney in a raid on a local Black Panther headquarters. The special prosecutor was held in contempt when he refused to obey the trial judge's order to call before the local grand jury every witness who had appeared before a federal grand jury. The contempt order was vacated on the ground that a trial court could exercise such power only "when failure to do so will effect a deprivation of due process . . . ." Id. at 16, 273 N.E.2d at 385.

A prosecutor's decision whether to press charges, representing a conscientious evaluation of the strength of evidence, should be beyond the control of any court. Yet it has been held that a judge may appoint a special prosecutor to proceed with a case if he disagrees with a decision not to prosecute. See State ex rel. Clyde v. Lauder, 11 N.D. 136, 90 N.W. 504 (1902). But see Gray v. District Court, 42 Colo. 298, 94 P. 287 (1908); see also State v. Flavin, 35 S.D. 530, 153 N.W. 296 (1915).

215. See V. NavaSKY, supra note 2, at 3-158.

216. See State ex rel. Jones v. Wurdeman, 309 Mo. 408 (1925). See also State v. Huett, 340 Mo. 934, 104 S.W.2d 252 (1937). But see Commonwealth v. Ryan, 188 A. 764 (Pa. 1936).

217. Continuance in office pending the resolution of charges seems warranted because a district attorney, like any other accused person, is entitled to a presumption 
Before state practices are adopted in the federal government, however, it should be noted that a local prosecutor operates in a system of diffused but autonomous executive power. A spécially appointed outsider can readily fit into this system because the district attorney he replaces is, in many respects, a severable unit. In contrast, the federal government is structured heirarchically, and an individual prosecutor cannot be severed from the rest of the system. Thus the practices that work well at the lower levels of state government may not provide a reliable solution to the federal problem.

\section{CONCLUSTON}

Whether executive power is concentrated, as in the federal governments, or diffused, as in the states, the problem of fair self-imvestigation reinains to be solved. Since the federal government has undertaken to investigate corruption at the highest levels of state government, the need to choose the best of the several alternatives at the federal level is particularly accute.

The wisest alternative is to avoid change in the structure of the federal system and to concentrate instead on its staffing. What is required is a forceful commitment by those sharing the constitutionally delegated appointment power to cease using law enforcement positions as rewards for service to a political party or candidate. That a President and sonie Senators have demonstrated a partial commitment to this ideal is an encouraging sign. It is now time for a universal commitment.

of innocence. Furthermore, his constituents, who have lawfully elected him, are entitled to the services of the person they chose; however, two countervailing considerations, neither of them previously recognized, point toward a requirement that the district attorney be suspended from his office pending a resolution of the charges against him.

First, a district attorney as a defendant will, of course, make use of every right available to other defendants. He will urge broad discovery and disclosure of investigative materials, and on any close question of law he will take the position most consistent with the defense of a criminal case. This in itself is perfectly proper. But in his capacity as district attorney in other matters, he may' urge narrow discovery and limited disclosure of investigative materials-thereby assuming a contrary position on the same Iegal issues. This process may weaken his effectiveness in his public position, denying the public the vigorous advocacy it deserves.

A second difficulty is that active continuance in office gives the district attorney an extraordinary advantage at trial. Certainly, it would not be prejudicial to an incumbent for him to state to the petit jury that he was elected district attorney and has temporarily stepped down pending the resolution of charges. This procedure was followed by Judge Kerner when he was indicted while sitting on the United States Court of Appeals. See United States v. Isaacs, 493 F.2d 1124, 1140 (7th Cir.), cert. denied, 417 U.S. 976 (1974). (Judge Kerner did not participate in judicial decisions after his indictment and resigned when his conviction was affirmed. 494 F.2d xvi (1974).) Yet the defendant who can state at trial that he is currently functioning as district attorney is likely to inflate his presumption of innocence by virtue of the public trust associated with his office. 
There is no guarantee that this alternative would insure a full investigation of a President should an occasion for such an investigation arise again. Nevertheless, separating law enforcement and partisanship will enhance the public status of law enforcennent officials, buttressing thein in a confrontation with a President. In any case, one should not focus so sharply on the presunably rare case of possible Presidential wrongdoing that one loses sight of the important objective of eliminating partisan control over lesser but nonetheless important governinent positions. Ironically, pohitical self-interest would probably prevent Congress froin adopting such a proposal. Yet, as particularly revealed by the Watergate experience, it is essential that law enforcenient and partisanship be severed. Nothing less has worked in the past; nor will anything else serve as well in the future. 